\title{
セニブラ社をふりかえって
}

王子化工株式会社 平 田浩

\section{Look back upon Brazil and CENIBRA My Experience at CENIBRA-}

Kou Hirata

Oji Kako Co., Ltd.

セニブラ社があるブラジルに就て一般的な概念から 述べると，日本人にとって“ブラジル”と云うとコー ヒー, カーニバル, アマゾン, ピラニヤ, サッカーの 王様ペレ或いは地球上で日本と正反対にあるところ等, 概して遠い国とは云うものの，何となく夢とロマンを 感じさせるものがある。しかし現実的に新聞紙上の報 道では世界一借金が多い，インフレが大きい等経済面 ではかなり苦しい中進国であることが判る。世界の景 気は好況と云われているが，これは先進国のみに当て 嵌ることで，一，二次産品を輸出する中進国にとって 現状は極めて厳しい。このグループに属するブラジル も懸命に努力しているが，仲々成果はあがっていない。
その中で外貨獲得の一部を担っている好業績のセニブ ラ社に駐在（1976 年 7 月より 1985 年 7 月）していた 間の見聞を紹介する。なお帰国後 5 年を経過し，業務 上も離れており正確さを欠くこともあると思うので御 了承を願う。またセニブラ創生期, 即ち建設より試運 転に関係した企業名は省略している。

\section{1. ブラジルの一般事情}

1）位置, 面積, 気候, 人口, 言語

ブラジルは南米大陸第一の大国で，赤道直下のアマ ゾンから南緯 34 度まで 南北 4,300 km, 東西 4,300 $\mathrm{km}$ の変形逆三角形を形成している。面積は約 851 万

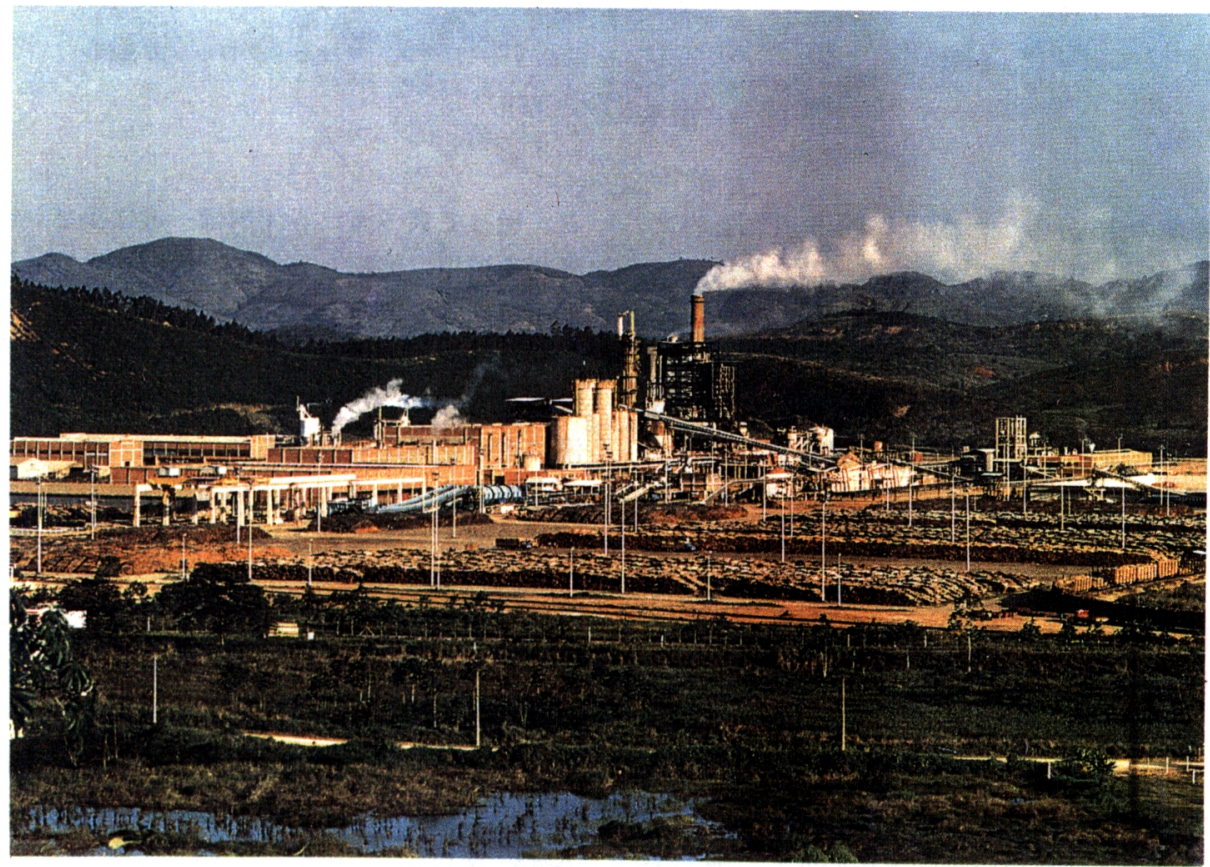

写真 1 セニブラ工場全景

ゲストハウスより望む 

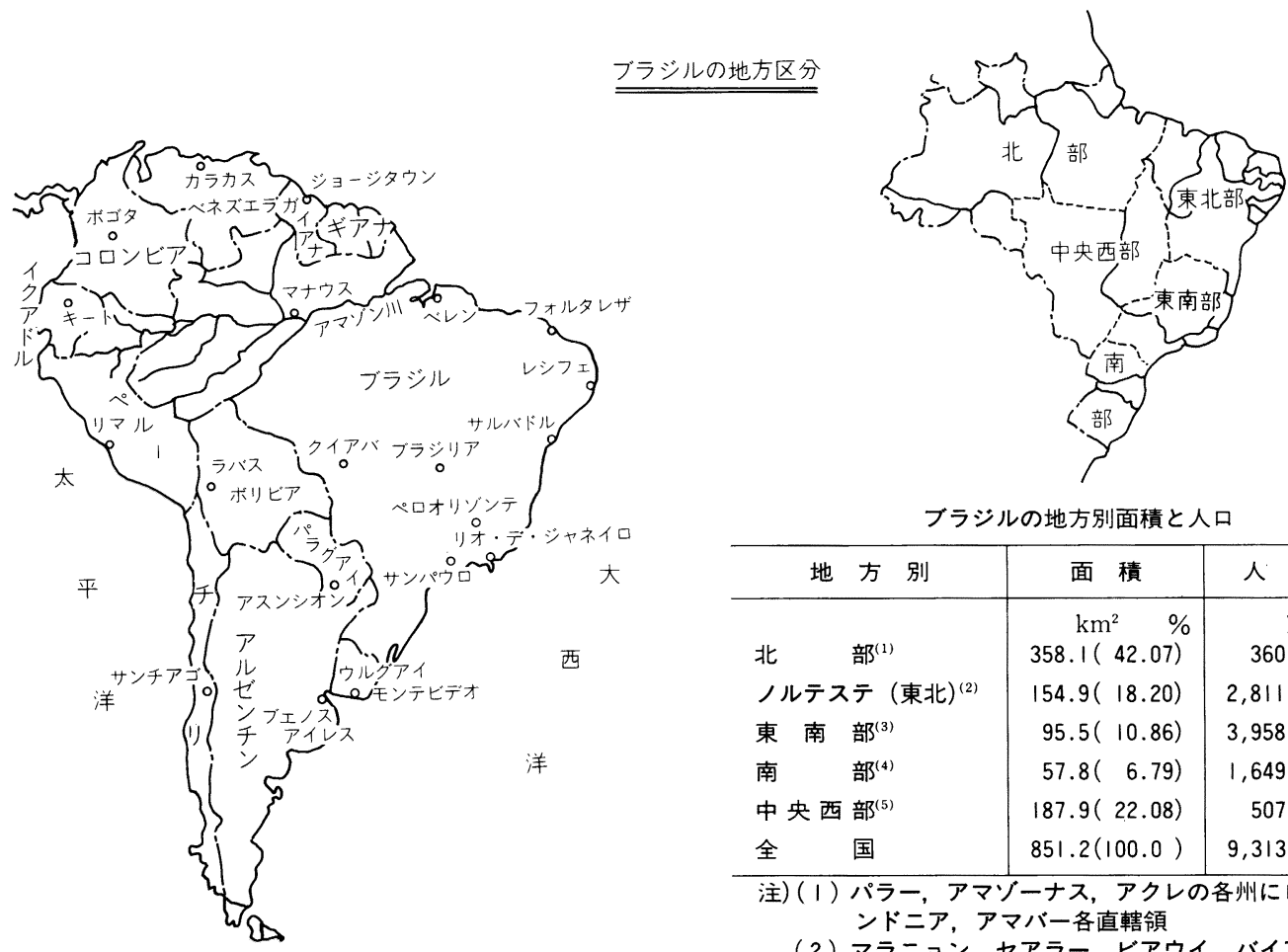

ブラジルの地方別面積と人ロ

\begin{tabular}{|c|c|c|}
\hline 地 方 別 & 面 積 & 人 口(1970) \\
\hline 部 ${ }^{(1)}$ & $\begin{array}{c}\mathrm{km}^{2} \\
358.1(42.07)\end{array}$ & $\begin{array}{c}\text { 万人 } \% \\
360.4(3.87)\end{array}$ \\
\hline ノルテステ $(\text { 東北 })^{(2)}$ & $154.9(18.20)$ & $2,811.2(30.18)$ \\
\hline 東 南 部(3) & $95.5(10.86)$ & $3,958.3(42.79)$ \\
\hline 部(4) & $57.8(6.79)$ & $1,649.6(17.71)$ \\
\hline 中央 西 部(5) & $187.9(22.08)$ & $507.3(5.45)$ \\
\hline 国 & $851.2(100.0)$ & $9,313.9(100.00)$ \\
\hline
\end{tabular}

注)( I ) パラー, アマソーナス, アクレの各州にロライマ, ロ ンドニア, アマバー各直轄領

（2）マラニョン, セアラー, ビアウイ, バイア, ペルナン フコ, パライパ, 北リオ,・グランテ, セルジベ, アラ ゴアスの各州とフェルナンド・ノロンニャ直轄領

(3) エスビリト・サント, ミナス・ジェラエス, リオ・デ・ ジャネイロ，グワナパラ，サンパウロ各州

(4) パラナ, サンタ・カタリーナ, 南リオ・グランデの各 州

（5）ゴヤス, マット・グロッソの各州

図 1 南米とブラジル

$\mathrm{km}^{2}$, 世界陸地の 16 分の 1 , 南米大陸の $41 \%$ を占め, 日本の 23 倍, ソ連, 中国, カナダ, アメリカに次いで 世界で 5 番目である。

気候の椂相は北半球とは全く逆である。南北に長い ため熱帯，亜熱帯，温帯の凡てを含み，さらに山間部， 内陸部，海沿いたよっても気候は全く異なる。熱帯， 亜熱帯では雨季と乾季があるが，気温的には日本と比 べると前者は夏, 後者は春 (又は秋) のみである。温 帯はほぼヨーロッパ並みの気候，しかし山間部では降 雪もあって四季の区別がある。一般に南部地方と云わ れ国土の開発が行き届き産業の中心地でもある。

地形は北方のアマゾン流域の他は大西洋側に沿って 海岸山脈が平行に迫っており，一方，南米大陸の骨格 であるアンデス山脈が大陸の太平洋側を北から南へ走 り，その東斜面がブラジル中央高原を形成し，概して 国土は高原地となっているのが特徵である。海岸山脈 に源を発する大部分の河川は内陸部に向って流れてい
る。従って東へ流れる河川は一般に小さいが, 内陸に 流れる河川は何れもアマゾン河，パラガイ河又はパラ ナ河の支流である。ブラジルと云えば，その全域が青々 とした熱帯の密林におおわれていると云う様に一般に は信じられているが，広大な大地ゆえ中央高原には砂 漠に近い乾燥地も沢山あり，今後の開発が待たれると ころである(七ラード開発と云う日本からの借款によ るプロジェクトもある)。

人口は約 1 億 4 千万人（1987 年現在）中国，イン ド，ソ連，アメリカ，インドネシアに次いで世界で 6 番目である。その構成は初期開拓者，宗主国であった ポルトガル人，アフリカから奴隷として連行された黒 人，原住民のインディオ，そしてこれらの混血とそれ ぞれの末裔に分けられる。その割合はおよそ $62 \%$ が白 人系, 褐色系が $26 \%$, 黒人系 $11 \%$, 残り $1 \%$ が日本 人などの黄色系である。

移民に就ては 19 世紀半ばに奴隷制が廃止されたた 

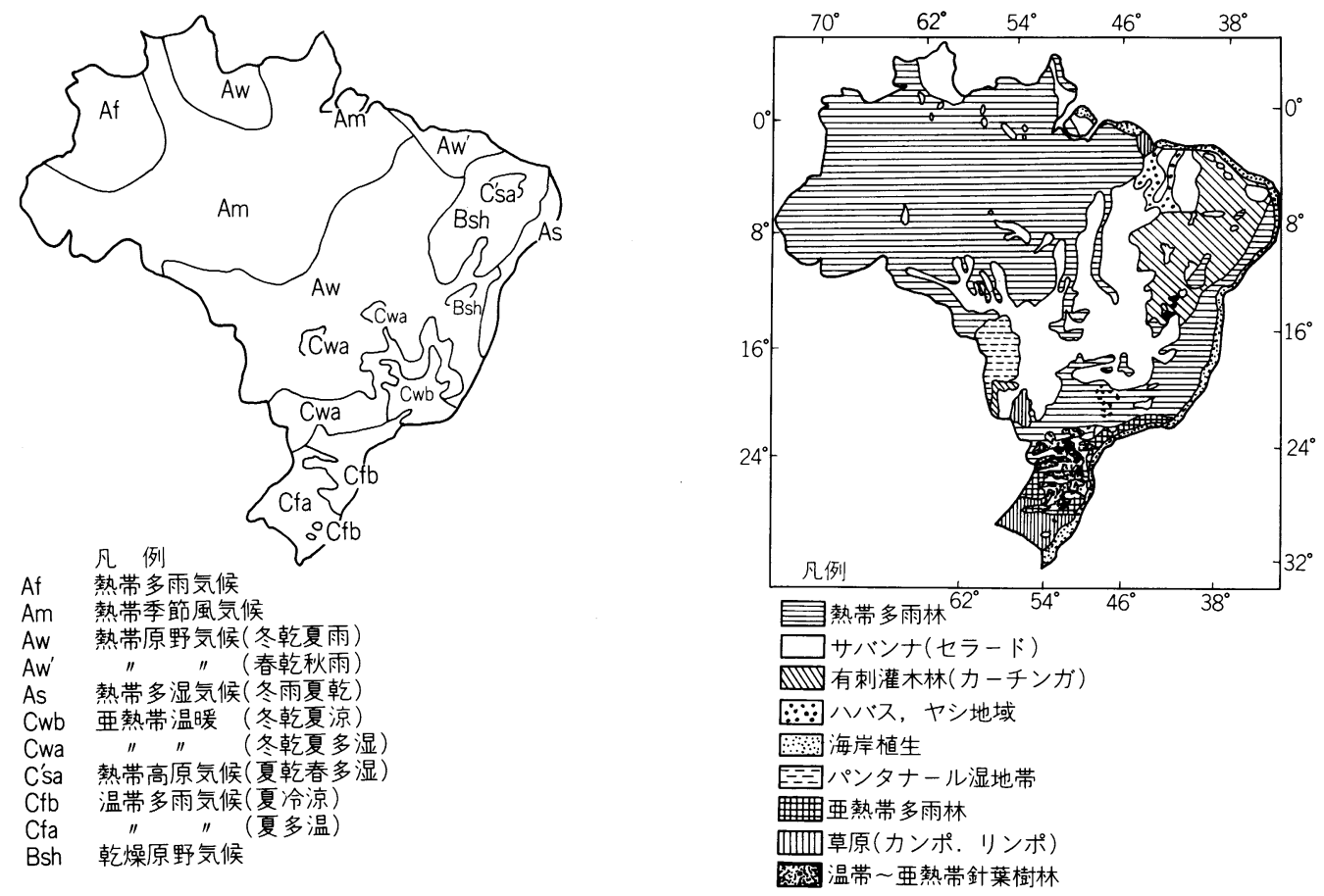

図 2 ケッペンによるブラジルの気候と植生
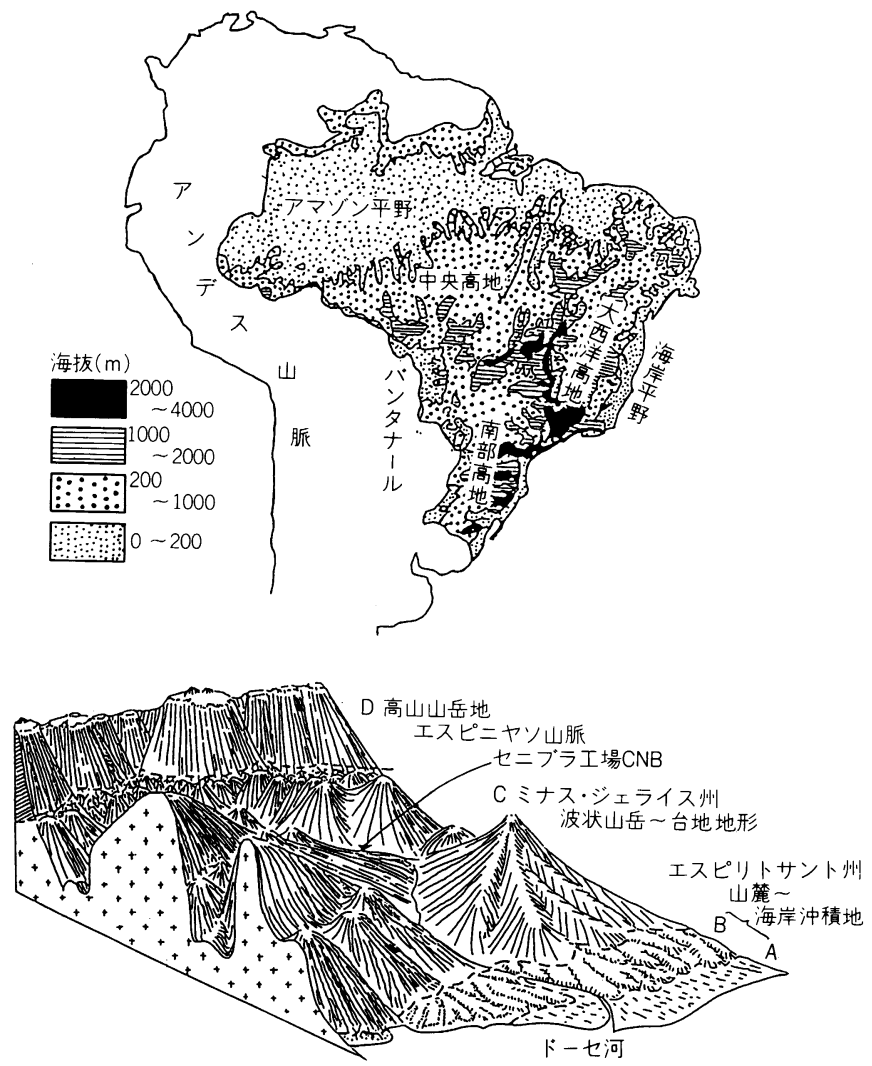

図 3 ブラジル及びミナ・スジエライス州の地勢 
め積極的な受入政策をとり，最近 100 年間でイタリ ア: 170 万, ポルトガル : 150 万, スペイン : 70 万, 日 本：23 万ドイツ：19 万などおよそ 500 万人を受入れ た。おな日本人は 1908 年, 笠戸丸で 167 家族 781 人の 移住が最初である。最近の人口は 1 世が 20 万, ブラジ ル生まれの 2 ないし 4 世が 95 万, 合わせて 115 万人と 云われている。職業別では農業が約 $50 \%$, 第三次産業 の卸・小売業が $17 \%$ ，サービス業が $13 \%$ ，その他 $20 \%$ と地方より都市部に集中化する傾向にある。

国語は本来, ポルトガル語であるが, ブラジル化し て意味も使い方も変ったものもあり，ブラジル人はブ ラジル語だと自称している。兄弟語であるスペイン語 は英語よりは通じやすい。

\section{2) 宗 教}

国民の 94\%がカトリック系で, 一部プロテスタント である。移住民はそれぞれ自国の宗教を持ち込んでい るものもあるが少数。どんな小さな寒村に行っても立 派な教会が建っている。

3）ブラジルの歴史の区分とその政治形体

歴史的に大まかに区分すると次の様になる。

（1） 植民地時代（1500～1822 年)

ポルトガル人ペドロ・アルバレス・カプラルによっ て発見されポルトガルの植民地となった。 320 年の間 にはヨーロッパ各国に侵略されかかったり，ポルトガ ル本国がナポレオン一世に侵略され，ブラジルに一時 的に避難する等のことがあった。

（2）帝政時代（1822１889 年）

ポルトガル王室の攝政ドン・ペードロ王子は王室が ポルトガルに引き揚げ後もブラジルに居残り, 1822 年 に独立を宣言しドン・ペードロ一世のもと立憲君主国 となった。

（3）第一次共和制（1889 1930 年)

王室内の権力斗争や奴隷解放, パラガイ戦争, アル ゼンチン戦争等で国内は疲弊し, 共和制思想の昂場で 1889 年, ドン・ペートロ二世は王位を追われ, 帝政は 二代で崩壊, 共和国の誕生となった。

（4）第二次共和制（1930１945 年）

ジェツリオ・バルガス大統領が独裁制を引いた。

（5）現代（1945～現在）

第二次世界大戦終結後, 軍部によりジェツリオ・バ ルガス大統領の独裁政治は終り, 再び共和制に戻った が, 悪性インフレは急進行を続け, 政治斗争は相変ら ず厳しさを加え，国家政体の左傾化が止まらず，1964 年, 陸海空の軍部が革命を起し, ここに軍事政権を開 いた。そして 1985 年 3 月, 21 年ぶりに民政移管 (PMDB/PFLの連立内閣) 直後, タンクレッド・ネー
ベス初代大統領の急死により副大統領のジョゼ・サル ネイが大統領に就任した。

なおジュセリノ・クビチェック大統領（1955１959 年）は新首都をブラジル国のほぼ中央部ゴイアス州に 建設しブラジリアと命名した。

4）ブラジル国名の由来

最初のブラジル探険隊によって持ち帰られた“バ ウ・ブラジル” (ブラジルの木) が国名の由来である。 この木はブラジル特産の高価な木材だが, もともとは 紅色染料の取れる木として珍重されており，監伐によ り殆ど取りつくされ，現在では高級家具などに僅かな がら使われている。

5）人種的偏見, 差別

黒人に対する同情と理解は深いが, 実生活では偏 見・差別が皆無とは云い切れない。植民地以来 400 年 の伝統で黒人, 原住民, その混血に対する偏見は希薄 になっている。しかし私自身の駐在中，見たこと，聞 いたこと, 或いは体験したことで明白なものは何もな かったが，肌身で何となく感ずるものが無かったとは 云い切れない。

6）国民性と風俗習慣

人種的にはブラジル人はポルトガル, スペイン, イ タリアを中心とする南欧ラテン系人種を基にして，ア フリカから連れて来た黒人と原住民のインディオ，こ れらが渾然一体となり，ラテン的な国民の気質を形成 しており，国民性の良い面も悪い面もラテン文化の影 響を強く受け継いでいる。即ち新しがり屋で好奇心が 強く, 情熱的で興奮しやすく, 物事に熱中するのも早 いが根気が無く飽きっぽい。移り気で付和雷同性があ り計画性に欠ける。また面子を非常に大切にする。“誇 り高きブラジル人”と云われる所以でもある。その他， 一般に親族の付き合いを重んじる。親子, 兄弟, 叔父 と叔母, 甥, 姪, 従兄弟はもとより, 配偶者の親族ま でとも親戚付き合いがあり, また名付親も大事な親戚 で，仲人も同じく親戚組織となる。具体的には親戚の 中で誰かが出世したり, 金持ちになると, 全員がより かかることが非常に多い。

\section{7）教育制度と文盲率}

ブラジルの文盲率は 15 才以上では $30 \%$ と云われて いる。政府は国家の基本問題として教育に力を入れ, 小・中学校 8 年間を義務教育として公立学校は無料で, 速やかに文盲率 0 へ向って努力している。しかしイン フレが大きく, 予算の不足で教師, 校舎とも不足, 三 部授業（午前, 午後, 夜間) を行っているが, 未だ目 標達成には至っていない。さらにアマゾンや奥地は広 大なため, 学校までが遠く就学率は低い。日本の僻地 


\section{とは桁が違う。}

高校は 3 年, 大学は $4 \sim 6$ 年。南部の都市の教育水 準が高いと云うことは落第が非常に多い他に宿題が山 の様にある。なお伝統のあるサンパウロ大学, リオ国 立大学への日系子弟の入学率は極めて高く, 教室に よっては半数以上を占めている。

\section{2. ブラジルの経済}

一般に南米各国は何れも日本人にとっては想像出来 ない様なインフレに悩まされているが，ブラジルも御 多分にもれず同じ傾向にある。これは後進国の宿命と も云える。何れも一次産品モノカルチャ一経済から脱 却すべく，工業化，インフラストラクチャーの整備等 に巨額の資金を導入，しかも後発国では民族資本は最 初から弱体であるため, 政府主導の官営型産業政策を とらざるを得ないが，これには経済成長と物価と国際 収支の天井の間での微妙な舵取りが必要となる。

1964 年 3 月のクーデターで発足したブラジル軍政 は，武力を背景とした強権の下に優秀なテクノクラー 卜を積極的に採用し，1960 年代末から 1970 代前半に かけ“ブラジルの奇蹟”を出現させ，インフレ率も $20 \%$ 代までおさえた。しかし 1983 年から 1985 年の 3 年間で，一次産品の輸出単価が $17 \%$ も下落したこと
と “ブラジルの奇蹟”に伴う消費増大及びインフレの 心理によりインフレが再発し（表 2 ）1985 年 3 月軍政 より民政に変った後も変化なく（1985 年は $235 \%$ の ンフレ) 1986 年 1 〜 2 月では月間 $15 \%$ に達し，1986 年 2 月末にインフレ抑制を目的とした下記内容の新経済 政策（クルザードプラン (1)～(4)）を実施した。

(1) $1 / 1,000$ のデノミ実施後通貨をクルザードと名付 けた。

表 1 物価上昇率の推移

(\%)

\begin{tabular}{|c|c|c|c|c|c|}
\hline \multirow{2}{*}{ 年 } & \multirow{2}{*}{\multicolumn{2}{|c|}{ 月 }} & & \multicolumn{2}{|c|}{ 総合物価指数（IGP） } \\
\hline & & & & 各 月 & 年初来累計 \\
\hline 1980 & 年 & 12 & 月 & 5.9 & 110.2 \\
\hline 1981 & 年 & 12 & 月 & 3.8 & 95.2 \\
\hline 1982 & 年 & 12 & 月 & 6.1 & 99.7 \\
\hline 1983 & 年 & 12 & 月 & 7.6 & 211.0 \\
\hline 1984 & 年 & 12 & 月 & 10.5 & 223.8 \\
\hline 1985 & 年 & 12 & 月 & 13.2 & 235.1 \\
\hline 1986 & 年 & 12 & 月 & 7.6 & 65.0 \\
\hline 1987 & 年 & 12 & 月 & 15.9 & 415.8 \\
\hline 1988 & 年 & 8 & 月 & 22.9 & 329.9 \\
\hline
\end{tabular}

（東銀資料）

表 2 ブラジル経済の推移一政権交代と経済計画一

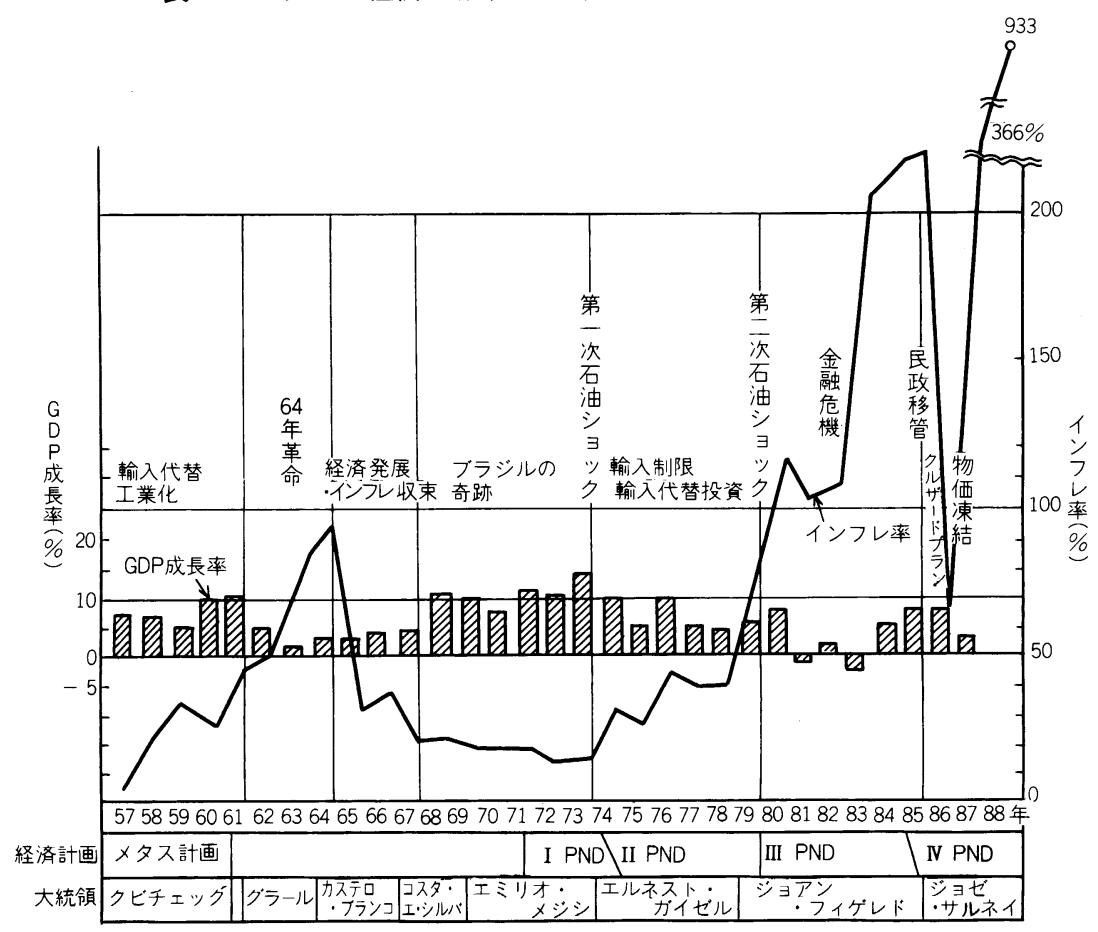


(2)物価，賃金（最低給料 $8 \%$ アップ後）為替凍結。

(3)価格修正制度の廃止（政府公定レートで全物価見 直し)

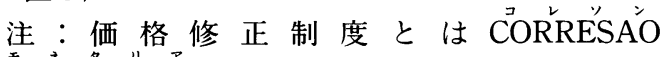

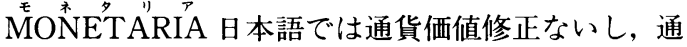
貨調整。ブラジル政府が 1964 年 7 月から採用して いるものでインフレによって生ずる名目価値と実質 価格との差を調整するユニークな制度。これは公共 料金, 住宅制度の割賦支払額, 家貨, 租税, 社会保 障拠出金，固定資産，運転資金の再評価，定期預金， 社債, 為替手形の額面修正等に適用されており, 価 值修正係数は企画省（1967 年迄は経済審議会）が決 定している。ザックバランに云うと我々の最も身近 な借金もこの係数で増える訳で日本とはこの点が異 なる。

(4)低金利政策

このクルザードプランは初期には成功したかに見え たが, 景気過熱と余りにも政争の具に使われたため弾 力的な運用を欠いて結局失敗した。したがってインフ レは以前にも増して加速（1987 年は 366\%）すると共 に貿易収支の大幅悪化に伴い，外国民間銀行団に対す る金利支払いを停止（モラトリアム）且つ価値修正制 度を復活した。また物価は依然凍結中，もしくは厳重 な監視下におかれた。1987 年の GNP 成長率は $2.0 \%$ で, 政府の社会計画及び人口成長率に必要な最低水準 を下迴った。

1988 年の経済は一旦破綻した経済の再建に終始し た。外債交涉再開，モラトリアム解除による対外信用 回復と, 政府の補助金カット, 増税, 公共料金引き上 げによる公共赤字抑制策が取られた結果, 強いス夕グ フレーションとなり, GNP は前年度比 $0.1 \%$ 減となっ た。しかしインフレは $933 \%$ と急上昇を続けストライ キは頻発した。

1989 年 1 月, 3 度目の奇蹟を求めインフレ抑制のた めの下記内容によるプラノ・ベロン (夏計画) (1) ～(5) を実施した。

(1) $1 / 1,000$ のデノミ実施後, 通貨呼称をニュークル ザードとする。

(2)物価・賃金（最低給料を $17.6 \%$ アップ後）を凍結

(3)為替は必用に応じて切り下げ実施

(4)価値修正制度を廃止, 高金利政策

(5)財政赤字の削減

以上の超インフレの諸対策を実施中であるが，国民 全体の意識改革がないと成功しないと云われている。

なお為替は 4 月 18 日 $3.27 \%$ 切下げられたが, 平行 相場（ヤミレート）と公定レートの差は約 2 倍となっ
ている。

また国際収支は殆ど毎年 “赤字”で改善が進むどこ ろか悪化している。このため政府は IMF の勧告を入 れる等努力しているが，現状では余程ドラスチックな 政策を行使しない限り不可能に近い。即ち債権・債務 両当事者の話合いを云うことになるが，相互の事情と 流動激しい世界経済のなかでは，難しいものが多すぎ る様に思う。

\section{3. ブラジルの産業}

1964 年以来の軍事政権下では国内の豊富な資源の 開発・活用をはかりながら，基幹産業である製鉄，造 船, 電力, 自動車産業等は “ブラジルの奇蹟”を産み 出す程に発展したが, オイルショックにぶつかり,すっ かり足踏みをしてしまっている。しかも“メがロマニ ア”と云われる程, 各プロジェクトは大きく巨大な投 資を行ったにも拘らず, ' 80 年初期の世界的な不況もあ り, 期待したほど輸出が伸びず債務累積の大きな要因 となり, 且つマネーサプライの急増はインフレを加速 させている。

しかし個々の産業に就ては新鋭設備の導入と豊富な 資源によるコスト面の優位さから鉄鋼，アルミ，紙パ ルプ, 食品加工, 産業機械, 造船, 紡績などは国際競 争力は非常に強い。

\section{1）鉄鋼・非鉄金属}

一貫製鉄所はすべて政府系で国策として能力増強が はかられて来た。1986 年の 2,123 万 $\mathrm{t}$ は最高の生産で 輸出は 720 万 $\mathrm{t}$ を越之た。“日伯合併の華”と云われた ウジミナスは 350 万 $\mathrm{t}$ の能力である。アルミは鉄鉱石 同様に豊富なボーキサイト及び電力があり, 外資系と して，アルコア，アルキャンと民族系 (CBA， VARESUL) が 2 社ある。日伯合併のアルブラスは 1985 年 10 月稼動, 当面は年産 16 万 $\mathrm{t}$, 最終的には 32 万 $\mathrm{t}$ 生 産を予定している。

2) 造船, 自動車

造船は国家的な助成措置と計画造船で急激に発展し た。日伯合併のイシブラスが最大手である。

自動車は 60 年代からワーゲン, GM, フィアット等 が続々と進出して最高 100 万台の生産実績がある。燃 料も行政指導で， $80 \%$ アルルコル車となっている。

3) 電気・電子機器

家電製品は外資系, 民族系が共存している。品質面 では未だ世界の一流品とは云い難い。

コンピューターは大型のものは制限つきながら, 外 資系による国産，一部輸入は可能。中小型機分野は行 政指導による輸入禁止で民族資本が手厚い保護を受け 
ている。

電力関連機器は外資系企業が早くから進出しており, 高い技術力で市場を独占している。シーメンス, 東芝, 日本電気，BBC，フィリップス等。

4) 化学工業

石油の自給率も $60 \%$ に達し, 石油化学コンビナート

も 3 力所あり製品の一部は輸出を始めた。

$$
\begin{array}{ll}
\text { クバトン (サンパウロ州) } & 36 \text { 万 } \mathrm{t} / \text { 年 } \\
\text { カマサリ (バイヤー州) } & 39 " \prime \\
\text { コペスール } & \\
\text { (リオ・グランデ, ド・スール州) } & 42 \quad "
\end{array}
$$

5) 繊維

繊維工業は豊富に生産される綿花から綿糸, 紡績に よる天然纎維工業が盛んで日本の有力紡績企業も多数 進出している。

6) 製靴

飼育されている牛は数億頭と云われ，その原皮を利 用して製靴業は目覚ましく伸び，1985 年には 8 億 US\$を主に欧米に輸出した。但し品質は二流品である。

7) 電方

豊富な水資源の有効利用と云うことで積極的に水力 発電設備の開発が進められて来た。特にブラジル, パ ラグアイの共同事業として建設されたイタイプ発電所 (外債 30 億 US $\$$ と云われている) は 1,260 万 $\mathrm{kW}$ と云 う世界最大の発電能力を有する（但し目下は $30 \%$ 発 電)。また東北部の将来の電力源として作られたツク ルイ発電所は 396 万 $\mathrm{kW}$ (最終は 796 万 $\mathrm{kW}$ ) の能力を 持つ予定である。1985 年末の発電設備能力は 3,947 万

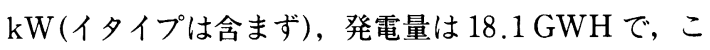
の中の $95 \%$ は水力発電によるものである。

8）石油・アルコール

1970 年代前半迄のブラジルの工業化は石油使用を 前提としていたが, 2 度にわたるオイルショックに伴 う価格の高騰 (1973 年から 1980 年にかけて約 10 倍) と自国産の石油供給率 $20 \%$ で貿易収支はすっかり赤 字になってしまった。このため

政府は (1)国内石油採掘量の增加

(2)自動車用燃料のアルコールへの転換

(3)輸入石油の代替として国内資源への転換

(例：セニブラの重油ボイラーがバーク

ボイラーへ変った)

の三項目を政策的に進め, 石油の自給率は 1985 年には $60 \%$ に増加, アルコール転換も1975 年の国家アルコー ル計画により砂糖きびの大増産と, アルコール抽出工 場に対する援助，ガソリンとアルコールの価格差維持, アルコール車への税制優遇措置等でアルコール転換は
急激に進んでいる。1985 年では自動車燃料のガソリン とアルコール比率は $1 ： 1,1988$ 年には $1 ： 4$ になっ ている。なお現在, 国内で販売されている乗用車（含 バン) の 95\%はアルコール車である。

\section{9）運輸}

陸上輸送はトラック, バスが主であり, 鉄道は総延 長 2.8 万 $\mathrm{km}$ (世界 8 位) の規模であるが, 便数が少な いので利用率も低く, トラック, バスに圧倒されてい る。

10）農業

ブラジルは熱帯から亜熱帯を経て温帯にまたがる広 大な大地を有し，農業による農産物は現在でこそ国の 政策で工業化に向い，貿易に占める割合も $40 \%$ 迄下っ て来たがその底力は素晴らしいものがある。特にコー ヒーはブラジルコーヒーとして世界に冠たるものがあ る。砂糖, とうもろこし, ココア, 綿花等の他に今後 は大豆, 果実, 果汁が大いに伸びるものと期待されて いる。

\section{4. 原木資源に就て}

ブラジルの森林面積は広大なアマゾンがあるので, 概略国土の $66 \%$ 近くを占めているが, 人工植林地は 700 万 ha で国土の $0.8 \%$ 前後と思われる。しかし植林 の歴史は古く 20 世紀初頃より始まったと云われ, 特 にユーカリ種の栽培は約 80 年程以前に始まった。ユー カリはオーストラリアが原産地であるが，これを導入 したところ気候, 風土, 土壤に合致したのか, 成長が 早くまたたく間にブラジル全土に拡がった。時恰も (1967 年) 国の緑化, 工業化推進のため植林インセン ティブ制が始まり，製鉄用木炭として急激に発展した。 特にユーカリが着目されて来たがその後, 松に就ても 盛んに研究が行われている。松属としてはテーダ松, エリオティ松, カリビア松, アラウカリア属として郷 土樹種のパラナ松等が対象となっているが未だユーカ リ程の成果は上っていない。

アマゾン流域の原生林は熱帯性多雨林で直接パルプ 用になるものは無い。また多種多様の混交林で伐採し ても輸送・選別を含利用するには非常に困難が多い。 この地区には JARI が原生林を伐採し，その跡地にパ ルプ原料材としてメライナ, ユーカリ，松等の植林事 業を行っているが, 湿地帯と大小の河川が無数に入り 混じっており，インフラの整備には莫大な投資を行っ ている。さらに所謂秘境と云われた地区であるため住 民も殆ど不在で，むしろ文明人は住めないと言っても 良い。

聞くところでは, アマゾン地方には石油を含む豊富 
な地下資源が眠っていると云われているが，ブラジル の意向はインフラの開発が始まるまで, 凍結に近い状 態にするとのことで，人工植林を含む開発は当面難し い様である。

国内中央高地のセラードは逆に雨が少なく乾燥して おり, 砂漠化している所や小さい貧弱な灌木が僅かし か生えていない所が大半で, 灌溉綱を含むインフラの 開発がないと植林を含め大規模な産業の開発は難しい。

一方, 大西洋沿岸と南部は適当な降雨量, 気温, 並 びに国土開発によるインフラもかなり進んでおり，用 地の取得がスムーズに行けば将来性は大いに期待出来 る。参考迄にセニブラ社の 1985 年の低目のユーカリ収 量 $(200 \mathrm{sT} / \mathrm{ha} \cdot 7$ 年) を用いると, パルプ年産 35 万 t に必要な土地面積は

必要原木量 35 万 $\mathrm{t} / \mathrm{Y} \times 5.6 \mathrm{sT} / \mathrm{t}=196$ 万 $\mathrm{sT} / \mathrm{Y}$

原木成長量 $200 \mathrm{sT} / \mathrm{ha} \div 7 \mathrm{Y}=\frac{200}{7} \mathrm{sT} / \mathrm{ha} \cdot \mathrm{Y}$

有効土地量 196 万 $\mathrm{sT} / \mathrm{Y} \div \frac{200}{7} \mathrm{sT} / \mathrm{ha} \cdot \mathrm{Y}$ $=68,600$ ha $(100 \%$ 利用可能として $)$

必要土地量 $\quad 68,600 \div 0.7=98,000$ ha (通常 70\%として)

約 10 万 ha の土地が必要となる。従ってブラジルの 国土全体を考えると土地は未だ無限にあると思われる。

注：sT ESTEREO, エステレオ $\mathrm{M}^{3}$ と云い, 層積 で実材ではこの 0.6 , 即ち $1 \mathrm{sT}=0.6 \mathrm{M}^{3}$

$5.6 \mathrm{sT} / \mathrm{t}$ ，パルプ $\mathrm{t}$ 当たり必要な層積エステ レオ $\mathrm{M}^{3}$

ユーカリが特に注目され大々的に植林された最大の 理由は, 並外れた成長量 $\left(20 \sim 30 \mathrm{M}^{3} / \mathrm{ha} \cdot \mathrm{Y}\right)$ と 7 年 伐期及び一回の植林で 3 回同じ周期で萠芽成長するた めコストが極めて低廉であることである。また後述の 樹種はLBKP としてその繊維の性質からティッシュ 並びに印刷・筆記用等に適している。

即ち日本の LBKP に比べてその特徵は

長所は (1)つか (かさ) が出易い

(2)引張り強度が高い

(3)不透明度が高い

短所は (1)引裂と耐折強度が低い

(2)表面強度が稍弱い (ベッセルピック)

等である。またユーカリ原木の各国のコストは下記の 如くブラジルが一番低い。

\begin{tabular}{|c|c|c|c|}
\hline & $\begin{array}{l}\text { 木材コスト } \\
\text { (パルプ } \mathrm{t} \text { 当り) }\end{array}$ & $\begin{array}{c}\text { 成長量 } \\
\mathrm{M}^{3} / \mathrm{ha} \cdot \mathrm{Y}\end{array}$ & 樹種 \\
\hline ブラジル & $51 \$$ & $25 \prime \prime$ & $\begin{array}{l}\text { グランジス } \\
\text { (Grandis) }\end{array}$ \\
\hline ポルトガル & $83 \prime \prime$ & $10 \prime \prime$ & $\begin{array}{l}\text { グロブルス } \\
\text { (Globulus) }\end{array}$ \\
\hline スペイン & $125 \prime \prime$ & 不明 & $\prime \prime$ \\
\hline 南アフリカ & 不明 & & " \\
\hline
\end{tabular}

また日本の LBKP に比べ製造上有利な点は

(1)単一樹種で若木であり, 同じ樹令であるためファ イバーが揃っている。

(2)上記により易漂白性で品質が安定

(3)日本では廃材が主であるが, ブラジルでは立木で あり伐採，バーキングが同一条件で行われるので 塵が極めて少ない。

等である。

ユーカリは約 600 種位あるが, コスト対策として更 に生産性が高く, パルプとして最適な樹種の研究が現 在も熱心に進められている。目下使用されている樹種 の使用割合は下記の通りである (ブラジルの場合で欧 州, 南アは異る)。

$\begin{array}{lll}\text { グランデイス } & \text { (Grandis) } & 70 \sim 20 \% \\ \text { サリグナ } & \text { (Saligna) } & 10 \sim 20 \% \\ \text { ウロフイラ } & \text { (Urophylla) } & 10 \%\end{array}$

パニキュラ夕 (Paniculata) 微量, 木炭用が多い テレチコルニス (Tereticornis) " ， "

注：1）製鉄用，木炭原料材としては上記以外の容 積重の高いものも植林され使用されている。

2) JARI で一時はなばなしく脚光を浴びたメ ライナ(Gmelina) は植林後, $3 \sim 4$ 年で成長 が止まると云うことで最近, 再研究されてい るが, 土㙵, 気候との相関もある様である。

針葉樹に就てはカリビア松 (Caribean pine) がアマ ゾンのアマパ (AMAPA) で植林され, 実際に 10 12 年でユーカリの 7 年生に相当する高成長性の樹種が開 発されており，JARI や海外に販売されている。

原木の研究に就ては大手の製紙・パルプメーカーが 何れも自社林を所有しているので, 各最新のバイオ技 術も組み入れて精英樹の開発・改良に取り組んでいる。 研究の過程では特に気候, 風土に影響なく何処でも成 長の良い種子の発見は未だ聞いていない。

紙パルプ業界の 1988 年の直接雇用者数は工業部門 で約 77,000 人, 山林部門で 46,000 人, 合計 123,000 人 となっている。 


\section{5. ブラジルの紙パルプ産業の現状と将来の展望}

\section{1 ブラジルの紙パルプ産業の現状}

ブラジルの紙パ産業は 1967 年の国の工業化政策に 則った各インゼンチブを利用して急激に伸張した。製 紙関係は 1970 年代初期より, パルプ関係は先進国の資 源確保に足並みを合わせる様に, ユーカリパルプの品 質が認知された 1970 年半ばより大規模工場が次々と 稼㗢している。

過去 10 年間 (1979 1988 年) に紙パルプの生産量は 2 倍となり, 年平均増産率はパルプは $7.6 \%$, 紙は $7.1 \%$ である

紙パ産業の構成メーカーは国内 17 州に及び, その数 は 191 社 236 工場があり, 民族資本系は 170 社, 残り は外資系である。原木から紙まで生産する一貫メ一
カーは 48 社, 紙のみを生産するメーカーは 98 社, メ カニカルパルプを生産するメーカーは 20 社, ケミカル パルプを生産するメーカーは 4 社である。

なお一貫並びにパルプ製造メーカーは何れも大・中 メーカーであり，一貫メーカーの製品は国内及び輸出 に供され, 非一貫メーカーは小企業で製品は国内に販 売される。パルプメーカーの生産量は国内パルプ総生 産量の $30 \%$ 占め, $75 \%$ が輸出されている。

1988 年は内需縮小型で国内経済が沈静化し, GNP は殆ど前年度と变らなかったが $(\mathrm{GNP}$ はー $0.1 \%$, 工 業生産は-0.3\%), 貿易収支は過去最高の 190 億ドル の黒字となった。紙パ部門も国際市況の需要增に支え られ, 輸出が大幅に伸び, 価格の高騰と共に販売高も 前年の $60 \%$ 増を上迴る 12 億ドルとなった。

製紙メーカー（表 5 ）は KLABIN, SUZANO,

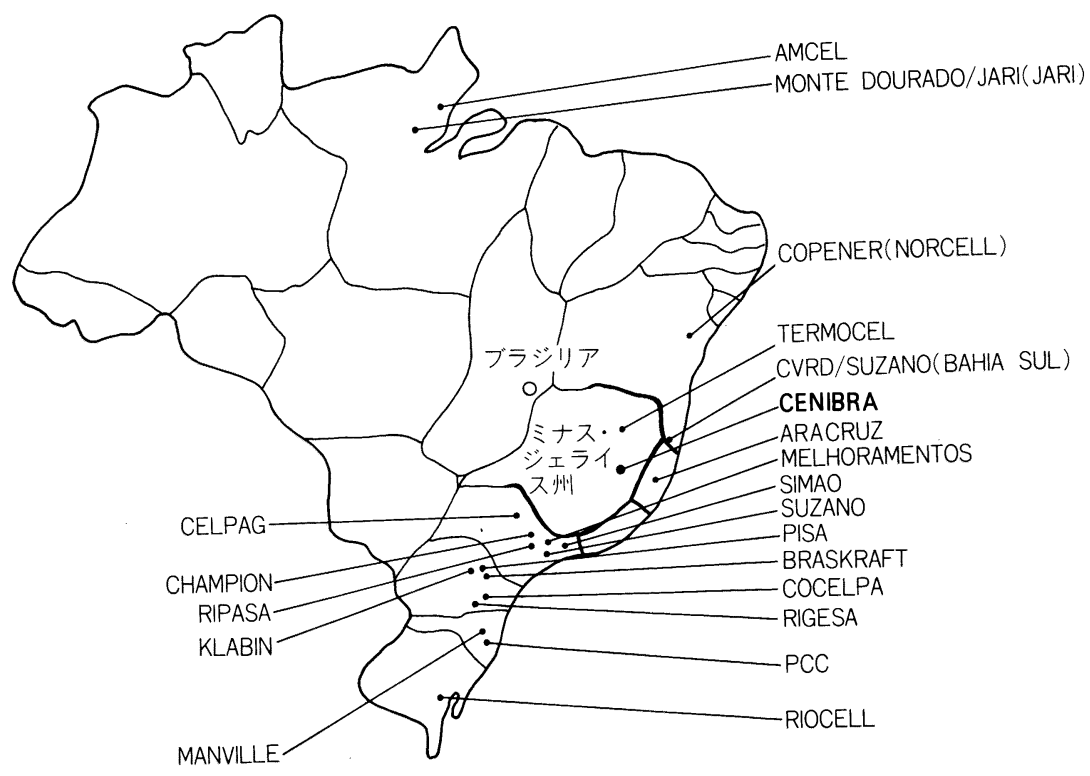

図 4 ブラジルの主要製紙, パルプ工場の所在地

表 3 ブラジルの紙品種別生産量（1970～1988）

$1,000 \mathrm{t}$

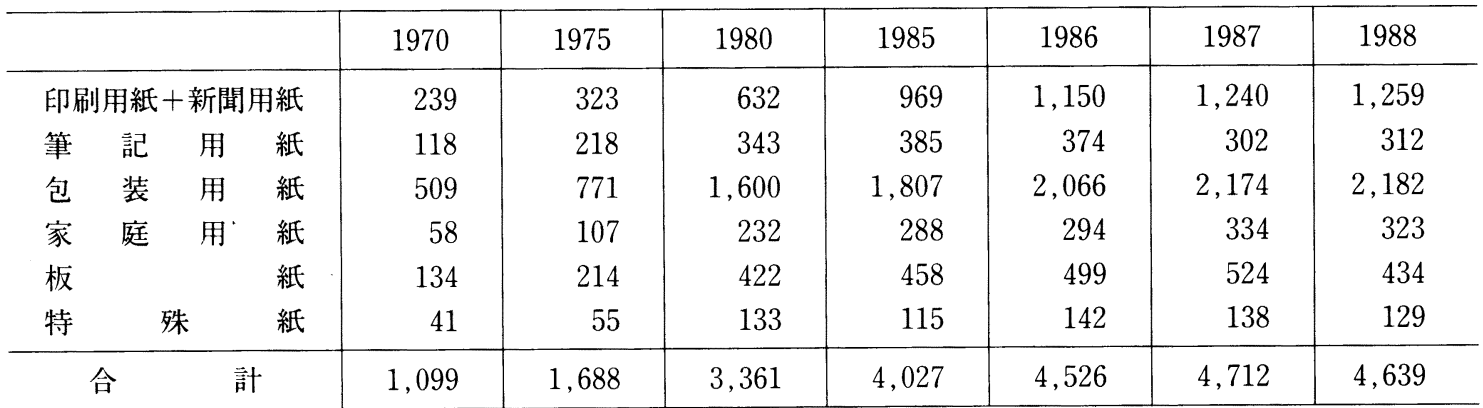

(伊藤忠資料) 
表 4 ブラジルのパルプ生産-自家消費-販売量（1970～1988）

$1,000 \mathrm{t}$

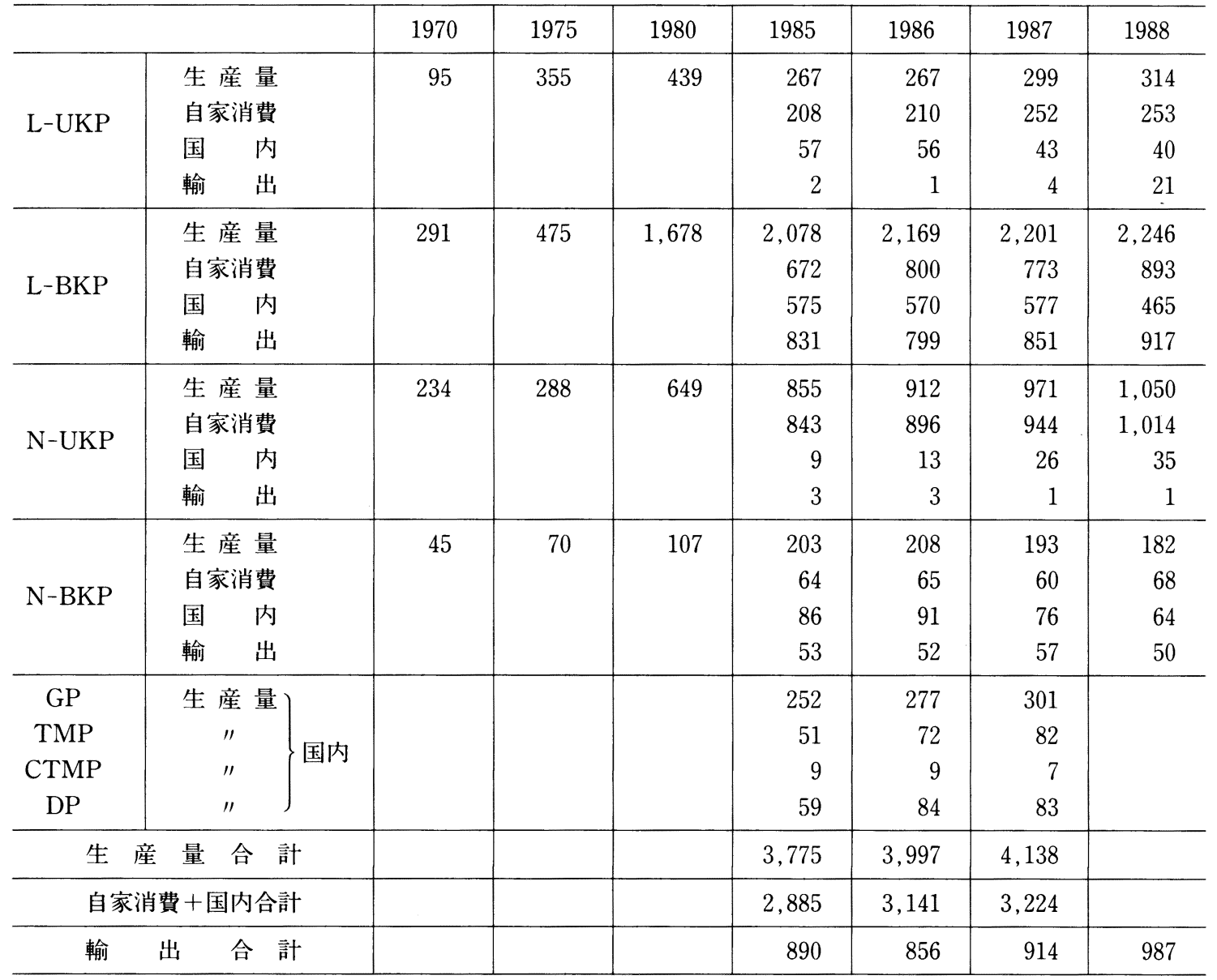

(伊藤忠資料)

SIMÃO, RIPASA, CHAMPION 各社の大手一貫メ一 カーグループ並びに準大手メーカー 7 社を入れ，その シェアーは $65 \%$ である（表 6 )。

パルプメーカー（表 7 ）は ARACRUZ, JARI, CENIBRA, RIOCELLの 4 社で, 国内パルプ生産の $30 \%$ のシェアを占めている (合自家消費)（表 8 )。パルプ 生産·輸出は 1988 年は前年に比し共に順調に増加して いる(それぞれ+3.5\%, +8.3\%)（表 9)。紙関係は生 産は若干低下 $(-1.5 \%)$ したが輸出は $57.8 \%$ と大幅に 増加した(表 10)。生産微减は国内景気の不景気, 特に 段ボール関係の消費減によるものと思われるが, 世界 的な紙需要増で上質紙及び包装紙は輸出増 $57.9 \%$ と なり 12 億 US\$の外貨を稼いでいる。

\section{2 一人当りの紙の消費量}

一人当りの紙消費量は輸出量の増大により, 国内向 けが減り 1988 年は低迷気味である。

1970 年 $13.7 \mathrm{~kg} /$ 人/年

$\begin{array}{lll}1985 " & 27.2 & \prime \prime \\ 1987 " & 30.7 & \prime \\ 1988 " & 27.5 & \prime \prime\end{array}$

即ち 1987 年迄は順調に伸びたが, 1988 年は 1987 年 に比し $3.5 \%$ 低下し 1985 年の水準に戻っている。

また輸入は CACEX (ブラジル銀行外国貿易局)によ ると 1988 年は前年と同じく 1.95 億ドルで, 内訳は LBKP 5.7 万 $\mathrm{t}$, 紙 (特に新聞用紙が 60\%) 19 万 $\mathrm{t} て ゙$ ある。

\section{3 紙パルプの需給予測}

1) 紙

紙の生産量はここ 10 年間で $7.1 \%$ の成長率である が, 最近 3 年間では $5.7 \%$ の伸びであり, 平均稼働率も $90 \%$ 前後に上昇し, 生産能力面でもかなり苦しい状況 である。特に新聞用紙を含む印刷用紙の伸びが $10 \% に$ 近くなっているが, 設備面での増設計画は表 11 の如く 1988 - 1992 年迄の 5 年間に 158.5 万 $\mathrm{t}$, 年率 $6.7 \%$ の 


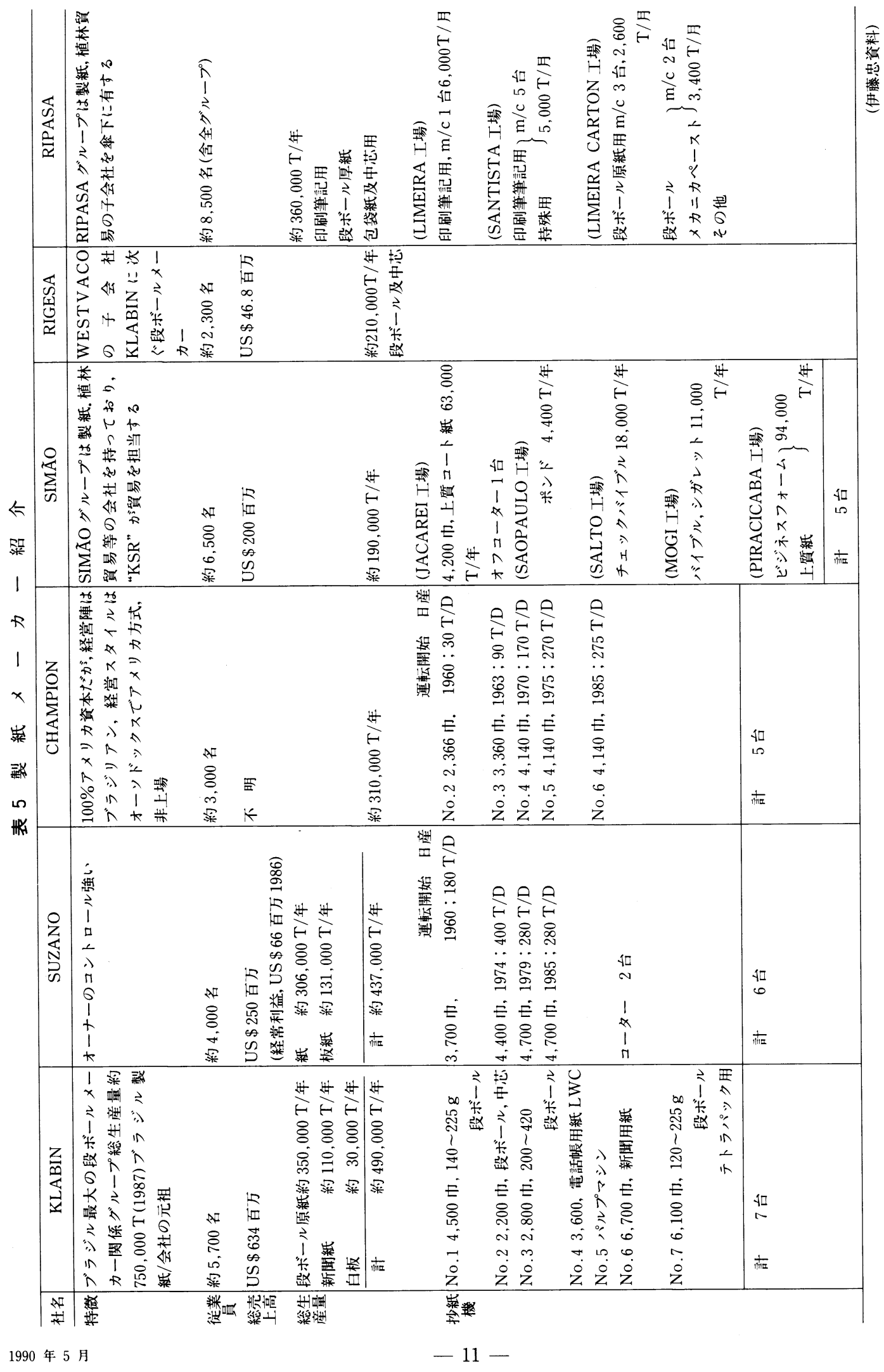


表 6 紙主要メーカー生産量

(Metric Ton)

\begin{tabular}{|c|c|c|c|c|c|c|}
\hline 社 & 1985 & $\%$ & 1986 & $\%$ & 1987 & $\%$ \\
\hline KLABIN Group ( 6 社) & 697,904 & 15.98 & 743,086 & 16.42 & 753,404 & 17.36 \\
\hline SUZANO Group ( 3 社) & 384,857 & 9.63 & 457,225 & 10.11 & 454,062 & 9.57 \\
\hline CHAMPION PAPEL E CELULOSE LTDA & 248,934 & 6.85 & 305,111 & 6.74 & 323,040 & 6.19 \\
\hline SIMAO Group ( 3 社) & 238,037 & 5.24 & 257,414 & 6.40 & 246,914 & 5.91 \\
\hline RIPASA Group ( 4 社) & 221,173 & 5.06 & 235,644 & 5.86 & 238,619 & 5.51 \\
\hline RIGESA, CEL. PAPEL E EMBS LTDA & 199,443 & 4.50 & 209,055 & 5.20 & 212,105 & 4.96 \\
\hline MANVILLE PROD. FLORESTAIS LTDA & 157,402 & 4.22 & 178,605 & 4.44 & 198,742 & 3.91 \\
\hline TROMBINT Group ( 3 社) & 115,214 & 3.00 & 134,929 & 3.36 & 141,633 & 2.86 \\
\hline PIZA-PAPEL DE IMPRENSA S.A. & 98,846 & 2.99 & 123,282 & 3.07 & 141,162 & 2.46 \\
\hline PAPIRUS INDUSTRIA DE PAPEL S.A. & 73,887 & 1.87 & 80,223 & 1.99 & 88,007 & 1.84 \\
\hline SANTA MARIA-CIA PAPEL E CEL. & 68,660 & 1.60 & 71,759 & 1.78 & 75,353 & 1.71 \\
\hline CIA INDUSTRIA DE PAPEL PIRAHY & 61,434 & 1.42 & 66,618 & 1.66 & 67,107 & 1.53 \\
\hline 他 & $1,455,609$ & 37.64 & $1,662,619$ & 32.97 & $1,774,476$ & 36.19 \\
\hline 計 & $4,021,400$ & 100.00 & $4,525,570$ & 100.00 & $4,714,624$ & 100.00 \\
\hline
\end{tabular}

(伊藤忠資料)

表 7 パルプメーカ一紹介

\begin{tabular}{|c|c|c|c|c|}
\hline 社 & CENIBRA & ARACRUZ & RIOCELL & JARI \\
\hline 特微 & 日伯合弁 & $\begin{array}{c}\text { 国内資本 } \\
\text { 単一生産ラインは世界最大 }\end{array}$ & KLABIN の系列 & 国内資本 \\
\hline 操 業 開 始 & 1977 年 & 1978 年 & 1970 年 & 1979 年 \\
\hline 生産高(1987) & 約 $351,000 \mathrm{t} /$ 年 & 約 $479,000 \mathrm{t} /$ 年 & 約 $246,000 \mathrm{t} /$ 年 & 約 $209,000 \mathrm{t} /$ 年 \\
\hline パルプの種類 & LBKP & LBKP & $\begin{array}{l}\text { LBKP } \\
\text { NBKP }\end{array}$ & $\begin{array}{l}\text { LBKP } \\
\text { NBKP }\end{array}$ \\
\hline 植林子会社 & 有 & 有 & 有 & 有 \\
\hline 原木自給率 & 1990 年より $100 \%$ & $100 \%$ & $100 \%$ & $\begin{array}{l}\text { 植林地は充分あるが， } \\
\text { 米だ } 100 \% \text { 見直しは } \\
\text { 不明 }\end{array}$ \\
\hline 増設計画 & 1992 年に $350,000 \mathrm{t} /$ 年 & $\begin{array}{l}1992 \text { 年に } 520,000 \mathrm{t} / \text { 年 } \\
(1 \text { 年位早くなる見込) }\end{array}$ & 1992 年に $350,000 \mathrm{t} /$ 年 & 明 \\
\hline
\end{tabular}

(セニブラ資料)

表 8 主要パルプメーカー 4 社の生産販売量

$(1,000 \mathrm{t} /$ 年 $)$

\begin{tabular}{|c|c|c|c|c|c|c|c|c|c|c|c|c|c|}
\hline & & \multicolumn{3}{|c|}{1985} & \multicolumn{3}{|c|}{1986} & \multicolumn{3}{|c|}{1987} & \multicolumn{3}{|c|}{1988} \\
\hline & & 生産 & 輸出 & 国内 & 生産 & 輸出 & 国内 & 生産 & 輸出 & 国内 & 生産 & 輸出 & 国内 \\
\hline ARACRUZ & LBKP & 470 & 356 & 126 & 476 & 337 & 142 & 479 & 343 & 138 & - & - & - \\
\hline CENIBRA & LBKP & 329 & 246 & 94 & 345 & 234 & 94 & 351 & 265 & 101 & 362 & 265 & 103 \\
\hline \multirow[t]{2}{*}{ JARI } & LBKP & 114 & 98 & 20 & 136 & 114 & 28 & 130 & 119 & 18 & - & - & - \\
\hline & NBKP & 87 & 47 & 42 & 89 & 45 & 47 & 79 & 59 & 35 & - & - & - \\
\hline \multirow[t]{2}{*}{ RIOCELL } & LBKP & 195 & 129 & 70 & 195 & 114 & 79 & 205 & 110 & 94 & - & - & - \\
\hline & NBKP & 47 & 2 & 47 & 47 & 2 & 46 & 40 & 46 & 30 & - & - & - \\
\hline \multicolumn{2}{|c|}{ Total } & 1,242 & 1,078 & 399 & 1,288 & 846 & 436 & 1,284 & 934 & 416 & & & \\
\hline
\end{tabular}

(伊藤忠資料) 
表 9 製紙用パルプ生産販売状況（対前年比）

$(1,000 \mathrm{t})$

\begin{tabular}{|c|c|c|c|c|c|c|c|c|c|c|c|c|}
\hline & \multicolumn{3}{|c|}{ 生産(対前年比) } & \multicolumn{3}{|c|}{ 一貫消費 (対前年比) } & \multicolumn{3}{|c|}{ 国内販売(対前年比) } & \multicolumn{3}{|c|}{ 輸出 (対前年比) } \\
\hline & 1987 & 1988 & $\begin{array}{l}\text { 差 引 } \\
(\%)\end{array}$ & 1987 & 1988 & $\begin{array}{c}\text { 差 引 } \\
(\%)\end{array}$ & 1987 & 1988 & $\begin{array}{c}\text { 差引 } \\
(\%)\end{array}$ & 1987 & 1988 & $\begin{array}{c}\text { 差 引 } \\
(\%)\end{array}$ \\
\hline LUKP & 299 & 314 & +5.0 & 252 & 253 & +0.4 & 43 & 40 & -6.9 & 4 & 27 & +42.5 \\
\hline LBKP & 2,201 & 2,246 & +2.0 & 773 & 893 & +15.5 & 577 & 465 & -19.4 & 851 & 917 & +7.8 \\
\hline NUKP & 971 & 1,050 & +8.1 & 944 & 1,014 & +7.4 & 26 & 35 & +34.6 & 1 & 1 & 0 \\
\hline NBKP & 193 & 182 & -5.7 & 60 & 68 & +13.3 & 76 & 64 & -15.8 & 57 & 50 & +12.3 \\
\hline Total & 3,664 & 3,791 & +3.5 & 2,029 & 2,228 & +9.8 & 722 & 604 & -16.3 & 913 & 989 & +8.3 \\
\hline
\end{tabular}

(伊藤忠資料)

表 10 紙及び板紙の生産及び販売量（対前年比）

$(1,000 t /$ 年 $)$

\begin{tabular}{|c|c|c|c|c|c|c|c|c|c|c|c|}
\hline & \multicolumn{3}{|l|}{ 生 } & \multicolumn{3}{|c|}{ 国内販売及自家消費 } & \multicolumn{3}{|c|}{ 輪 } & \multicolumn{2}{|c|}{ 稼動率 (参考) } \\
\hline & 1987 & 1988 & 差引\% & 1987 & 1988 & 差引\% & 1987 & 1988 & 差引\% & 1986 & 1987 \\
\hline 新 聞 用 紙 & 232 & 247 & +6.5 & 215 & 235 & +9.3 & 17 & 10 & -4.1 & $89 \%$ & $95 \%$ \\
\hline 印刷／筆記用紙 & 1,310 & 1,324 & +1.1 & 933 & 846 & -9.3 & 369 & 473 & +28.2 & 96 & 88 \\
\hline 包装 用 紙 & 2,174 & 2,182 & +0.4 & 1,912 & 1,665 & -12.9 & 222 & 460 & +107.2 & 94 & 94 \\
\hline ティッシュ & 334 & 323 & -3.3 & 328 & 308 & -6.1 & 2 & 9 & +35.0 & 91 & 88 \\
\hline 力 $-卜 ン$ & 524 & 434 & -17.2 & 489 & 382 & -21.9 & 21 & 49 & +133.3 & 95 & 85 \\
\hline 特 殊 & 138 & 129 & -6.5 & 131 & 122 & -6.9 & 6 & 4 & -33.3 & 85 & 79 \\
\hline Total & 4,712 & 4,639 & -1.5 & 4,008 & 3,558 & -11.2 & 637 & 1,005 & +57.8 & 92 & 87 \\
\hline
\end{tabular}

成長率になりまだ若干の余裕は持っている。

2) パル プ

紙が年率 $6.7 \%$ 伸びるとすると, 必要パルプ量は 176 万t $(158.5 \div 0.9)$ が必要となるが, パルプ設備はこ の 5 年間に 286 万 t が増設される計画（表 12）であ り，製紙用に使われた残りの余剩パルプ 110 万 $\mathrm{t}$ は輸 出されることになる。従って 1992 年末のパルプ輸出能 力は 195 万 t $(85+110) に な り$, 輸出ドライブは更に かけられることになるが，一方では貴重な外貨稼ぎに なる。ただ問題はこれに必要な資金と原木の調達とな ろう。

3）増設に伴う必要原木量

現在, 製紙・パルプメーカーが所有している原木量 は, 未だ必要量の $70 \%$ しか自給出来ず残りは独立山林 会社から購入している。この対策は

\section{(1)植林地の購入}

286 万 $\mathrm{t}$ のパルプに必要な土地は 4 項の試算による と 286 万 t $\div 35$ 万 t $\times 10$ 万 ha $\fallingdotseq 82$ 万 ha となる。

(2)成長性, 収量に勝れ且つ病虫害, 気象害に対し抵 抗性のある精英樹の開発。
の二点にしぼられる。ユーカリが成木になるには現在 では 7 年を要するため速やかな手段を立てて対応しな いと，逆にパルプ用原木の不足をきたし，ブラジルは 紙パルプの輸入国に落ち込む馝念さえもある。参考迄 に 82 万 ha の植林に必要な投資額はインフラを除い て 7 年間で 10 億 US\$を越えるものと思う。

4) ま と め

ブラジルの紙パルプ産業は広大な土地と恵まれた気 候・風土・及びユーカリと云う製紙用パルプに有力な 樹種を発見して開発された。従って原料は再生産がで き無尽蔵に近い。また労働力はやや質は悪いが適切な 企業内教育で対応できる。問題の一つは必要資金であ るが,こう云った有利な条件があれば，海外からの投 資も行われ，自然と飛躍的に発展するものと思う。問 題の二つはインフラであり，これは民間では仲々困難 でどうしても政府の力が必要になる。かかる面の配慮 が行われる官民一体の体制が整えば, ブラジルは近い 将来，世界の LBKP 供給センターとしての役割を果 し，慢性的な国際収支の赤字から脱却するのも夢では ないと思う。 
表 11 製紙メーカーの新・增設予定（1988～1995）

$1,000 \mathrm{t} /$ 年

\begin{tabular}{|c|c|c|c|c|c|c|c|c|c|}
\hline & & 1988 & 1989 & 1990 & 1991 & 1992 & 1993 & 1994 & 1995 \\
\hline $\begin{array}{l}\text { 新 } \\
\text { 聞 } \\
\text { 刷 } \\
\text { 刷 } \\
\text { 筆 } \\
\text { 望 }\end{array}$ & $\begin{array}{l}\text { RIPASA } \\
\text { PISA } \\
\text { SiM̃AO } \\
\text { CHAMPION } \\
\text { IGUASU } \\
\text { KLABIN } \\
\text { FACELPA } \\
\text { CELPAG } \\
\text { INPACEL }\end{array}$ & 40 & 10 & $\begin{array}{r}160 \\
\\
\\
26 \\
120 \\
\end{array}$ & 240 & & $\begin{array}{r}110 \\
7\end{array}$ & 285 & 191 \\
\hline $\begin{array}{l}\text { 包 } \\
\text { 装 } \\
\text { 用 }\end{array}$ & $\begin{array}{l}\text { KLABIN } \\
\text { BAHIA Sul } \\
\text { ONOUNONE } \\
\text { REgESA } \\
\text { PRIMO TEDESCO } \\
\text { FACELPA } \\
\text { CATARINENSE } \\
\text { IRANI } \\
\text { MoRRo VERDE }\end{array}$ & 10 & & $\begin{array}{r}150 \\
36 \\
\\
\\
\\
\\
36 \\
69 \\
\end{array}$ & 90 & 50 & 230 & 48 & \\
\hline $\begin{array}{l}\text { 衛 } \\
\text { 告 } \\
\text { 他 }\end{array}$ & $\begin{array}{l}\text { SANTA TEREZINHA } \\
\text { MinikRAFT } \\
\text { CATARINENSE }\end{array}$ & 13 & & 150 & $\begin{array}{c}40+23 \\
58\end{array}$ & & & & \\
\hline $\begin{array}{l}\text { 板 } \\
\text { 紙 } \\
\text { 中 } \\
\text { 芯 }\end{array}$ & $\begin{array}{l}\text { LIMEIRA } \\
\text { BATTISTELLA } \\
\text { RIPASA }\end{array}$ & & & & 28 & $\begin{array}{r}115 \\
44\end{array}$ & & & \\
\hline 特殊紙 & Santa Terezinha & & & & & 30 & & & \\
\hline & 総 & 63 & 10 & 747 & 526 & 239 & 347 & 333 & 101 \\
\hline
\end{tabular}

\section{6. セニブラ社発展を振り返って}

\section{1 プロローグ}

セニブラ社 (CELULOSE NIPO-BRASILEIRA S.

A. 略称 CENIBRA) は日本の紙パルプ産業とブラジル の官営企業であるリオ・ドーセ社 (COMPANHIA VALE DO RIO DOCE, 略称 CVRD) との合弁会社 で,ブラジルのユーカリより LBKP を製造するために 1973 年 9 月設立され, 工場はブラジル MG 州のべロ・ オリエンテ (BELO ORIENTE, 以下 B. O と略す)

に建設, 1977 年 9 月より操業を開始, 1988 年は 36 万 t の LBKP を生産している。

日伯の出資比率は日本側 $48.5 \%$, ブラジル側 $51.5 \%$ で日本が技術と資金を, ブラジル側が資源と労働力を
提供するものである。日本側が基本設計及び主要設備 の選定, 建設工事並びに操業指導, マネージメント及 び保全部門の技術移転等を行い, 当初計画の $40 \%$ 上 廻る生産を続けている。

本プロジェクトの経緯に就ては, 当初セニブラ計画 の他に，日本側が原木資源の確保と云う意味もあって， エスピリット・サント州に植林会社フロニブラ（EMPREENDIMENTOS FLORFSTAIS S. A.) を日伯 合弁で設立, 約 16 万 ha の土地を購入, 一部は植林ま で行っていたが，1975 1980 年の世界的な紙パ産業 の長い不景気, チップ輸出の不採算とプラジル側の チップ積出港建設中止のため 1983 年 11 月セニブラの 植林会社に発展的解消を遂げた。従って現在はセニブ ラ・フロレスタル社として CVRD 社に代ってセニブラ 
表 12 パルプメーカーの新・増設予定（1988～1995）

$1,000 \mathrm{t} /$ 年

\begin{tabular}{|c|c|c|c|c|c|c|c|c|c|}
\hline \multicolumn{2}{|c|}{ メーカー名 西 暦 } & 1988 & 1989 & 1990 & 1991 & 1992 & 1993 & 1994 & 1995 \\
\hline $\begin{array}{l}\text { 高 } \\
\text { 步 } \\
\text { 留 } \\
\text { パ } \\
\text { ル } \\
フ^{\circ}\end{array}$ & $\begin{array}{l}\text { TERMCCEL } \\
\text { PISA } \\
\text { BATTISTELLA } \\
\text { SERRA co CABRAL } \\
\text { FACELPA } \\
\text { IRANI } \\
\text { INPACEL }\end{array}$ & & & $\begin{array}{l}24 \\
18 \\
96 \\
\end{array}$ & $\begin{array}{l}100 \\
250\end{array}$ & $\begin{array}{l}115 \\
100\end{array}$ & & & \\
\hline $\begin{array}{l}\mathrm{L} \\
\mathrm{B} \\
\mathrm{K} \\
\mathrm{P}\end{array}$ & 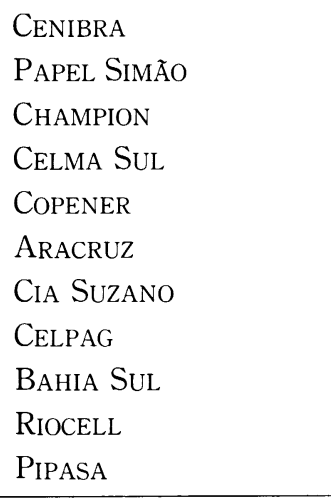 & 140 & 36 & 300 & $\begin{array}{l}350 \\
\\
520 \\
\end{array}$ & 350 & 340 & $\begin{array}{l}131 \\
350\end{array}$ & 112 \\
\hline $\begin{array}{l}\mathrm{N} \\
\mathrm{B} \\
\mathrm{K} \\
\mathrm{P}\end{array}$ & $\begin{array}{l}\text { CATAIRINENSE } \\
\text { M ARCO VERDE } \\
\text { TGUASU }\end{array}$ & & & 50 & 123 & & $68+34$ & & \\
\hline $\begin{array}{l}\mathrm{N} \\
\mathrm{U} \\
\mathrm{K} \\
\mathrm{P}\end{array}$ & $\begin{array}{l}\text { KLABIN } \\
\text { PRIMO TEDESCO } \\
\text { FACELPA } \\
\text { IRANI } \\
\text { MORRO VERDE } \\
\text { RIGESA } \\
\end{array}$ & & $\begin{array}{r}150 \\
51 \\
11\end{array}$ & $\begin{array}{l}23 \\
52\end{array}$ & & & & & 31 \\
\hline & 計 & 140 & 248 & 563 & 1,343 & 565 & 442 & 917 & 143 \\
\hline
\end{tabular}

ح必要な原木の供給, 植林伐木及び林地の購入, ユ一 カリ精英樹の研究開発に取り組んでいる。具体的には 従来持っていた E. S. 州の植林地と CVRD 社がミナ ス・ジェライス州（以下 M. G と略す）に持っている 土地と等価交換した訳で，これでセニブラは原木から の完全な自給体制を取ることになった。

\section{2 ゼニブラ B. O. 工場}

ゼニブラ社は本社を M. G 州々都ベロ・オリゾンテ 市に置き，工場は同市より $230 \mathrm{~km}$ 離れたべロ・オリエ ンテ郡カショエイラ・エスクーラのドーセ河左岸に建 設され, 135 ha の工場敷地には巨大な生産設備を含め 9.6 万 $\mathrm{M}^{2}$ の建屋がそびえている。従業員は工場
1,100 人, 本社 200 人で合計 1,300 人弱であり, JBP 派遣者は工場 6 名, 本社 4 名, 山林関係 3 名の合 計 13 名である。会社の組織は表 16 に示す通りであり 操業は 5 組 4 交代制をとっている。

従業員は工場より $30 \mathrm{~km}$ 及び $80 \mathrm{~km}$ 離れたイパチ ンガ市及びゴベルナドール市から社用バスで通勤し， その比率は 40 及び $60 \%$ である

先ず原料であるが，現生産で 36 万 $\mathrm{t} /$ 年を維持する 為には原木 250 万 ST (重油代替用原木を含む) が必要 であり，これ等の原木は工場周辺の植林地(約 $200 \mathrm{~km}$ 以内）からトラック又は貨車で運ばれて来る。なお皮 剥きは伐採地, 駅土場及び工場ドラムバーカーで行わ 


\begin{tabular}{ll} 
平 田 浩 \\
\hline
\end{tabular}

表 13 七ニブラ社の概要

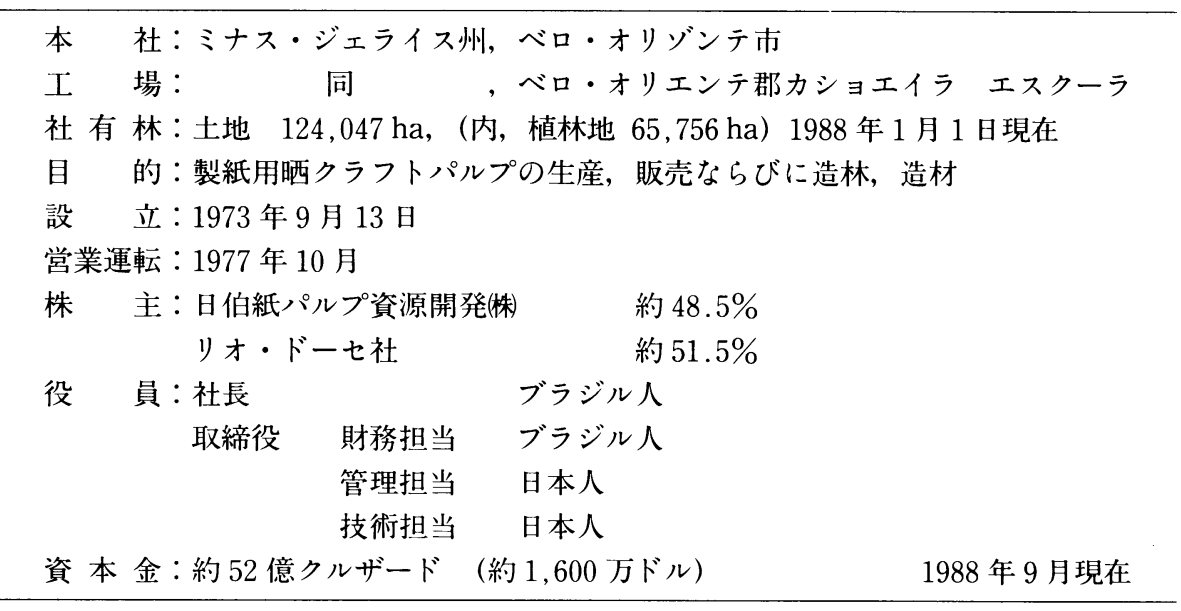

表 14 セニブラ・フロレスタル社の概要

本 社：ミナス・ジェライス州 ベロ・オリエンテ (セニブラ工場内)
事業地：

目的：セニブラ社有林の管理, 造林, 造材および輸送

設 立: 1983年11月 1 日

役 員: 社 長 ブラジル人

取締役 山林担当 日本人

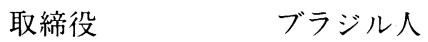

取締役旦本人

資本金：約 5 億 9 千万クルザード(約 180 万ドル） 1988年 9 月現在

組織および従業員：

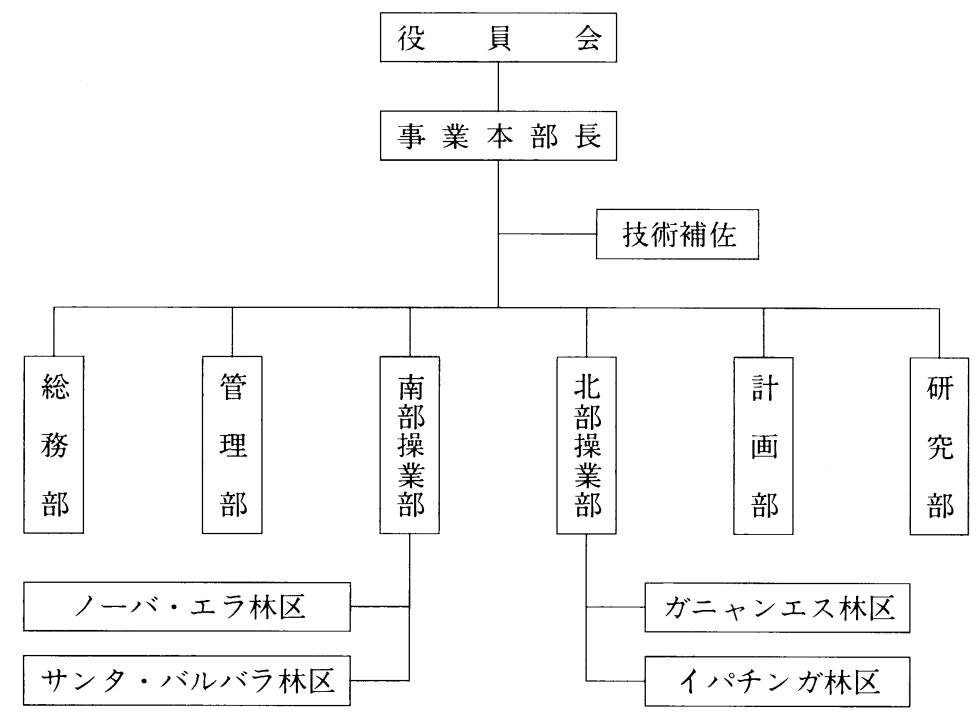

本 社 140 人(JBP 派遣員 3 名)

林 区 3,673 人
合
計 3,813 人

1988年 8 月現在 
表 15 ベロ・オリエンテ工場概要（1989 年 1 月現在）

所 在 地：ミナス・シェライス州ベロ・オリエン

テ郡カショエラエスクーラ

(日伯合弁のウジミナス製鉄所のあ

るイパチンガ市より $26 \mathrm{~km}$ 東方)

工 場 敷 地：工場周辺 1,200 ha の中の 135 ha, そ の他は植林地

従 業 員: 1,100 人

製品：製紙用ユーカリ $\mathrm{BKP}$

生 産 量: 年産 35 万 $\mathrm{t}$ (日産 $1,030 \mathrm{t}$ )

営業運転開始：1977 年 9 月 30 日

社 有 林：総面積 125.0 千 ha

植 林 面 積:

70.0 千 ha

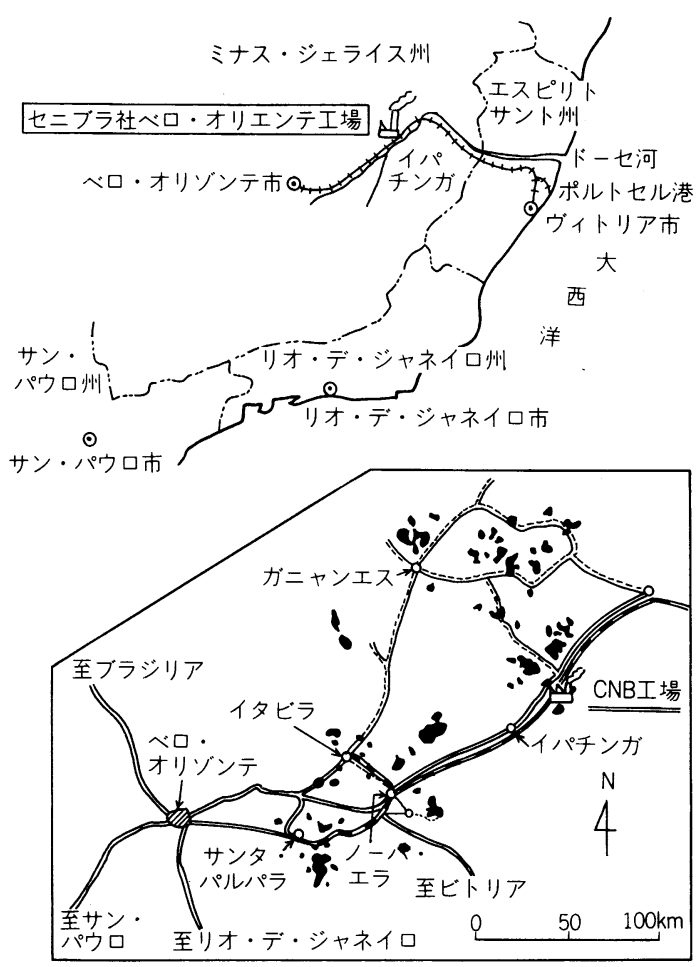

図 5 B. O 工場および社有林位置図

れる。ユーカリの特性として樹皮は伐木後 2 週間以内 に又は 2 カ月後でないと極めて剝きづらい。

生産されたLBKPはリオドーセ社の鉄道を使って $400 \mathrm{~km}$ 離れたパルプ積出港ボートセルに送られ日・ 米・欧に積出される。国内は工場より直接トラックで 目的地へ陸送される。

製紙工場で原木に次いで最も重要なものの一つであ る工場用水はドーセ河より 1 日 13 万 $\mathrm{M}^{3}$ 取水される。 水質は赤褐色の濁水で鉄, マンガンを含んでいるが,
一次処理沈澱で良好となる。また公害規則が厳しくな り，従来の排水処理では規制値をクリア出来ないため 活性污泥装置を 1988 年末に新設し調整運転中である。

外貨節減のため, ブラジル政府の行政指導で燃料転 換, 即ち重油より木材に変更, 1985 年 7 月より新ボイ ラーに切替り重油節減目標値に到達した。回収ボイ ラーも稼働後ほぼ 12 年を経過, 増産による負荷も最大 となって来たので, 1990 年末の完成を目途にもう一段 大型のボイラーを建設中である。

\section{3 設備 \\ 1) 調 木}

当初, 原木はすべて山元で剝皮し工場土場に持ち込 んでいたが, 燃料転換に伴う重油代替燃料として, 原 木及び樹皮が使用されることにより（1985 年 7 月ス タート）原則として搬入原木は皮付きとなり，ドラム バーカーで剝皮することになった。また燃料用として 原木がチップ化されるので, チッパー及び燃料用チッ プ土場が新設された。前記ドラムバーカーで除去され た樹皮や折損材等は良材と分離され，燃料用チップ土 場を経由して，バークボイラーに送られる。必要な原 木原単位はプロセス用として $5.55 \mathrm{sT}=$ 皮無/パルプ $\mathrm{t}$,

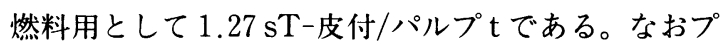
ロセス系チッパーから土場迄は風送であったが, チッ プの細裂化が甚だしいので，コンべヤに更新された。 またチップの不揃いと増産による蒸解条件の変更もあ り, 粕率のアップでチップの足を若干短くしている(1" $\left.\rightarrow 5 / 8^{\prime \prime}\right)$ 。

搬入される原木は長さが $2.2 \mathrm{~m}$, 最小径が $70 \mathrm{~mm}$ 以上と云うことであるが, ドラムバーカーでは細材の 折損が多く，これ等が移送コンベヤを含めて土場関連 各設備でプラッギング（詰り）等のトラブルを起し易 い。樹種はグランジス, サリグナ, ウロフィラの三種 だがグランジスが $90 \%$ 占めている。

2）蒸解・洗滌・未晒精選

増産のため Kamyr Digester の蒸解ストレーナーの 位置を $3 \mathrm{~m}$ 下げたため, 八イヒート部の容積減少に伴 う洗滌悪化対策として Diffusion Washer 1 系列増 設, 並列 2 系統で洗滌強化をはっかている。更に未晒 精選に就ても発泡, 排水及び節水対策としてクローズ ドシステムに改善，一連の工事は 1986 年に完成した。 3) 晒

CEHDED の 6 段晒は晒能力として通常の 5 段に比 べ遙かに余裕があり, セニブラパルプの高白色度と各 晒段での極めて良好な原単位に寄与している。その薬 品原単位は日本国内メ一カーの $60 \%$ 程度である。そ の後, 排水対策及び一層の原単位向上のため $\mathrm{E}$ 段に 


\begin{tabular}{ll} 
平田浩 \\
\hline
\end{tabular}

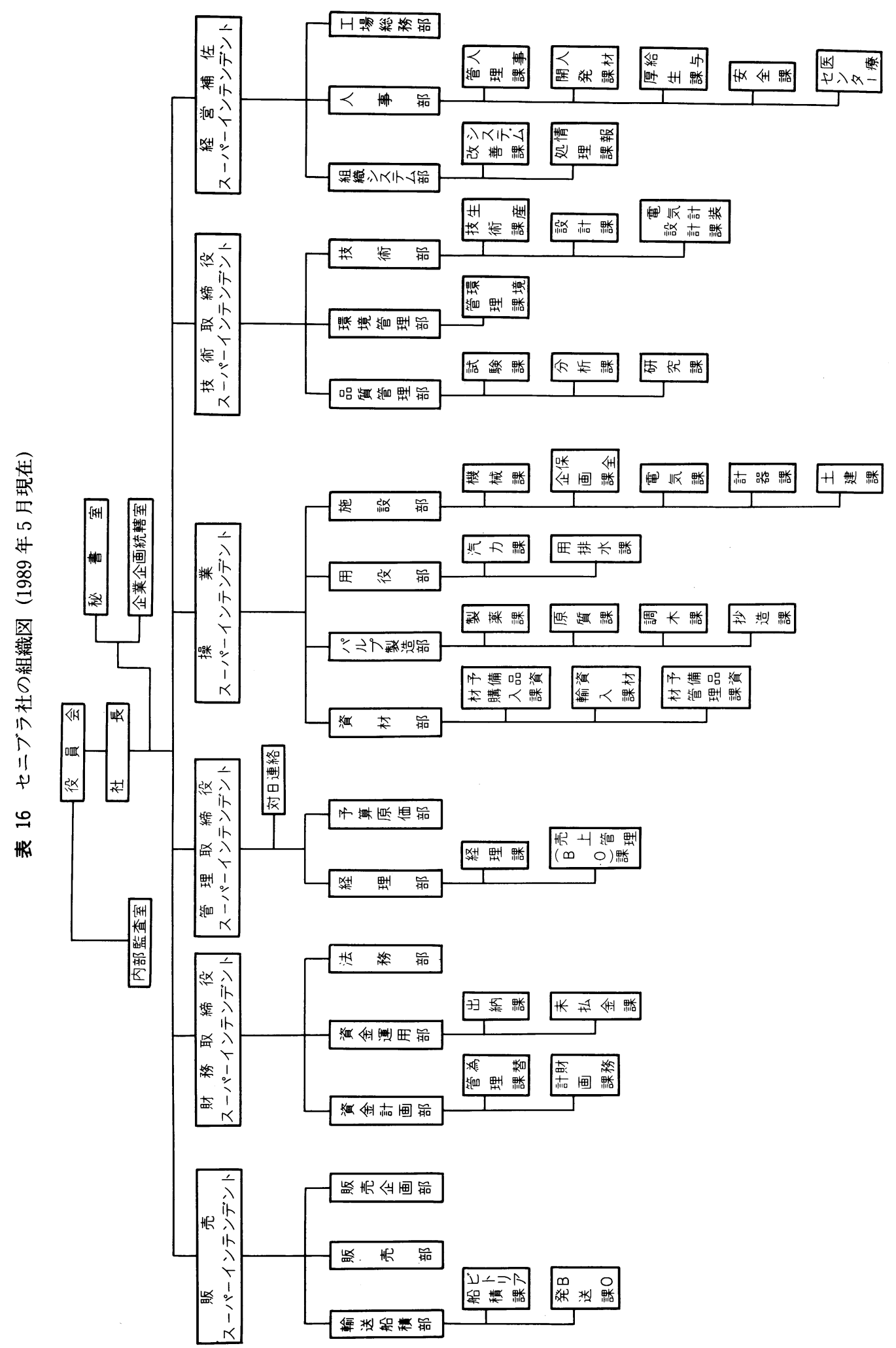




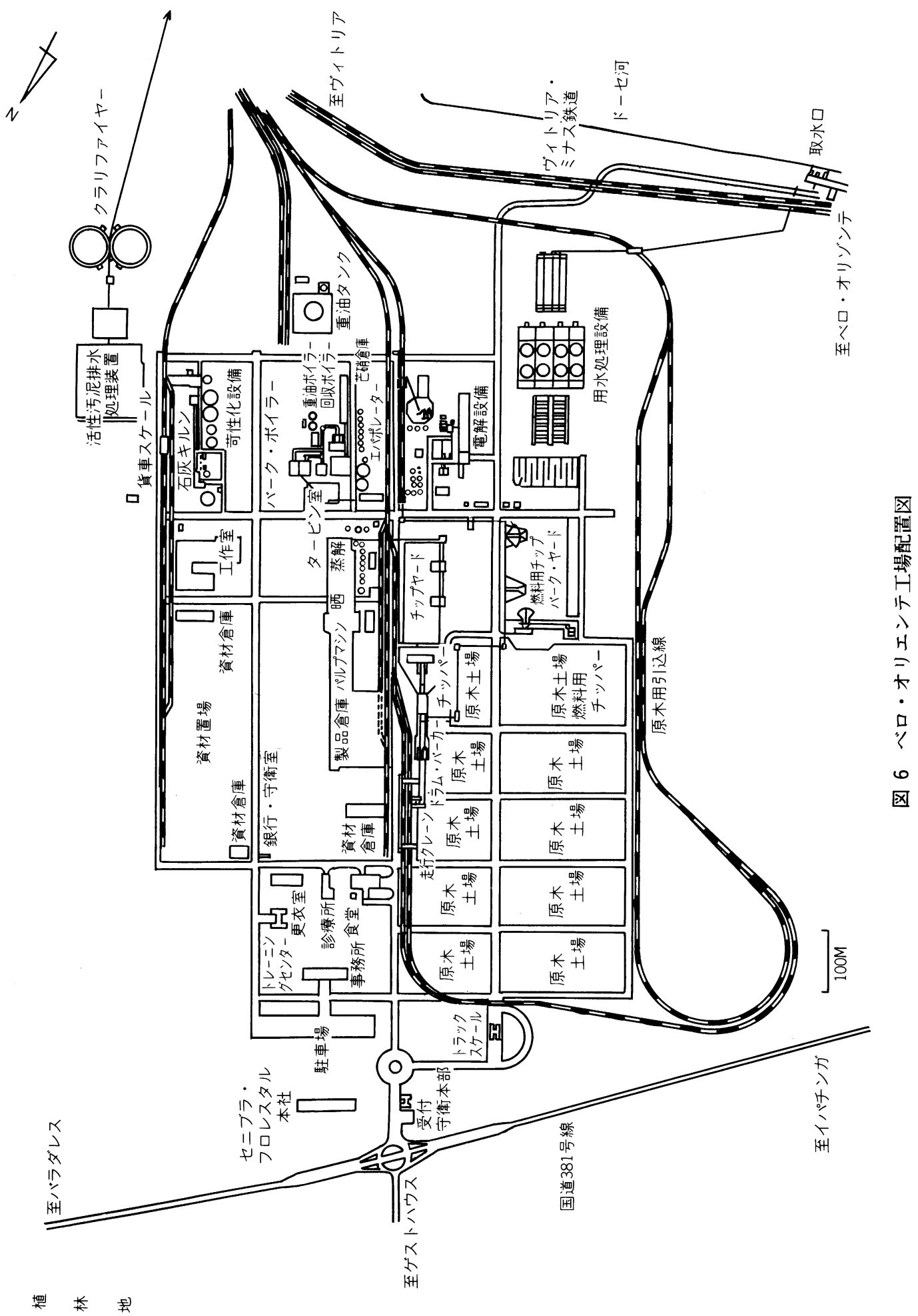




平田浩

表 17 工 場 設 備 概 況

(LBKP 1,000 ADT/D)

\begin{tabular}{|c|c|c|c|c|}
\hline 工 程 & & 概 & & 設備メ一カ一 \\
\hline 木 & $\begin{array}{l}\text { ドラムバーカー } \\
\text { パルプ用チッパー } \\
\text { 同上用スクリーン } \\
\text { 燃料用チッパー } \\
\text { 同上用スクリーン } \\
\text { 各種ハンドリング言 }\end{array}$ & 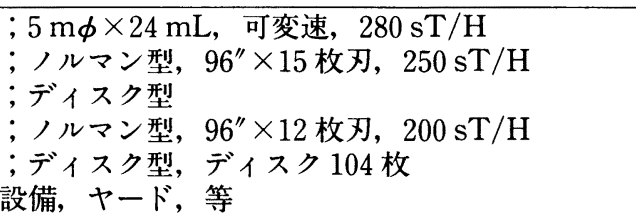 & \begin{tabular}{l|}
2 式 \\
2 式 \\
2 式 \\
1 式 \\
1 式
\end{tabular} & $\begin{array}{l}\text { ARECO } \cdot \text { ANDRITZ } \\
\text { CARTHAGE } \\
\text { C.F.FUNDICAO } \\
\text { C.F.FUNDICAO }\end{array}$ \\
\hline 解 & $\begin{array}{l}\text { ダイゼスター } \\
\text { 洗 浄 設 備 } \\
\text { 未晒スクリーン }\end{array}$ & $\begin{array}{l}\text {; 気相/液相, ハイヒート付 } \\
\text { KAMYR 連続鉒 }\left(1,106 \mathrm{~m}^{3}\right) \\
\text {; ディフューザーウォッシャー } \\
\text { ドラムウォッシャー } \\
\text {; 遠心式/ッター } \\
\text { コーワン型スクリーン } \\
\text { セントリソーター } \\
\text { シックナー }\end{array}$ & $\begin{array}{l}1 \text { 式 } \\
2 \text { 基 } \\
1 \text { 台 } \\
3 \text { 台 } \\
6 \text { 台 } \\
2 \text { 台 } \\
1 \text { 台 }\end{array}$ & $\begin{array}{l}\text { KAMYR } \\
\text { KAMYR } \\
\text { 清朝機械 } \\
\text { S.W.HOOPER } \\
\text { INGERSOLL RAND } \\
\text { INGERSOLL RAND } \\
\text { INGERSOLL RAND }\end{array}$ \\
\hline 白 & $\begin{array}{l}\text { 晒 設 備 } \\
\text { 晒スクリーン }\end{array}$ & $\begin{array}{l}\text {; C-E/O-H-D-E-D 6 段晒 } \\
\text { 晒搭 (ニンクリート製) } \\
\text { 晒フイルター } \\
\text {; ロータリースクリーン, 遠心式クリーナ } \\
\text { シックナー/エキスト }\end{array}$ & $\begin{array}{l}1 \text { 式 } \\
6 \text { 基 } \\
6 \text { 台 }\end{array}$ & $\begin{array}{l}\text { CODRASA } \\
\text { INGERSOLL RAND } \\
\text { JYLHA, CELLECO } \\
\text { 清朝機械 }\end{array}$ \\
\hline 抄造仕上 & $\begin{array}{l}\text { パルプマシン } \\
\text { ドライヤー } \\
\text { カッター } \\
\text { 仕上梱包 }\end{array}$ & $\begin{array}{l}\text {; 長網式, ワイヤー巾 } 5,200 \mathrm{~mm} \\
\text {; フクドライヤー,F.C.型 } \\
\text {; オンマシンレイボーイ付 } \\
\text { 1,000Tプレス } \\
\text { ラッパー, タイイングマシン, ユニタイザー }\end{array}$ & $\begin{array}{l}2 \text { 基 } \\
2 \text { 基 } \\
2 \text { 基 } \\
2 \text { 台 } \\
2 \text { 式 }\end{array}$ & \begin{tabular}{|l} 
VOITH \\
FLAKT \\
LAMB GRAYSHARBER \\
AHLSTROM \\
CRANSTON \\
\end{tabular} \\
\hline 苛 性 化 & $\begin{array}{l}\text { 苛性化設備 } \\
\neq \text { キ } \\
\text { [付] } \\
\mathrm{SO}_{2} \text { 製造設備 }\end{array}$ & $\begin{array}{l}\text {; DORR 式連続苛性化設備 } \\
; 3.3 \mathrm{~m} \phi \times 104 \mathrm{~mL} \\
; \text { ロータリーサルファーバーナー } \\
\mathrm{SO}_{2} \text { 製造設備 }\end{array}$ & \begin{tabular}{l|}
1 式 \\
1 基 \\
1 式
\end{tabular} & $\begin{array}{l}\text { DORR OLIVER(B) } \\
\text { F.L.SMITH }(\mathrm{B}) \\
\text { BELOIT }(\mathrm{B})\end{array}$ \\
\hline $\begin{array}{l}\text { エバポレ } \\
\text { ーター }\end{array}$ & \begin{tabular}{|ll} 
蒸 発 缶 \\
\end{tabular} & $\begin{array}{l}\text {; H.P.D.式 } 7 \text { 缶 } 6 \text { 重効用 (LTV 型) } \\
\text { 強制循環式コンセントレーター付 } \\
\text { 黒液濃度 } 15 \% \rightarrow 62 \%\end{array}$ & 1 式 & CONFAB \\
\hline $\begin{array}{l}\text { 回収ボイ } \\
\text { ラー }\end{array}$ & $\begin{array}{l}\text { ボイラー本体 } \\
\text { 電気集塵機 }\end{array}$ & $\begin{array}{l}\text {; ラージエコ付低臭気式 } 2 \text { 胴水管型 } \\
\text { 固形分 } 1,440 \mathrm{~T} / \mathrm{D}, \text { 蒸気 } 65 \mathrm{~K} \times 450^{\circ} \mathrm{C} \times 205 \mathrm{~T} / \\
; \text { コットレル型 }\end{array}$ & \begin{tabular}{c|c|}
1 基 \\
2 基
\end{tabular} & $\begin{array}{l}\text { 三菱重工 } \\
\text { GEMA }\end{array}$ \\
\hline $\begin{array}{l}\text { 重油ボイ } \\
\text { ラー }\end{array}$ & $\begin{array}{l}\text { ボイラー本体 } \\
\text { (休缶中) }\end{array}$ & $\begin{array}{l}; 2 \text { 胴水管型, } \mathrm{VU}-60 \\
; \text { 蒸気 } 65 \mathrm{~K} \times 450^{\circ} \mathrm{C} \times 200 \mathrm{~T} / \mathrm{H}\end{array}$ & 1 基 & 三菱重工 \\
\hline $\begin{array}{l}\text { バイオマ } \\
\text { ス・ボイ } \\
\text { ラー }\end{array}$ & ボイラー本体 & 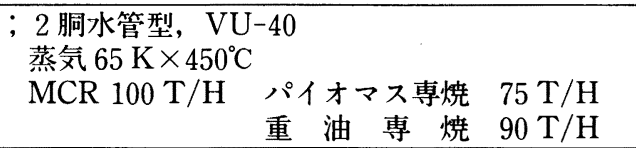 & 2 基 & C.B.C \\
\hline 発 電 所 & $\begin{array}{l}\text { タービン } \\
\text { 発 電 機 } \\
\end{array}$ & $\begin{array}{l}\text {; } 2 \text { 段抽気復水式, } 40,000 \mathrm{~kW} \\
; \text { ブラウンボバリー式 }\end{array}$ & \begin{tabular}{l|l|}
1 基 \\
1 基
\end{tabular} & \begin{tabular}{|l|l} 
東 芝 \\
BROWN BOVERY (B)
\end{tabular} \\
\hline 薬 & $\begin{array}{l}\mathrm{Cl}-\mathrm{Al} \text { 電解 } \\
\\
\text { クロレート電解 } \\
\mathrm{ClO}_{2} \text { 発生設備 }\end{array}$ & $\begin{array}{l}\text {; ダイヤモンドシャムロック方式 } \\
\text { 隔膜法電解槽 } \\
\mathrm{Cl}_{2} 46 \mathrm{~T} / \mathrm{D}, \mathrm{NaOH} 52 \mathrm{~T} / \mathrm{D} \\
\text {; ケメテックス方式 } \\
\text {; } \mathrm{ERCO}-\mathrm{R} 3 \text { 方式 } \\
\mathrm{ClO}_{2} 7 \mathrm{~T} / \mathrm{D}\end{array}$ & $\begin{array}{r}32 \text { 槽 } \\
\times 4 \text { 列 } \\
1 \text { 式 }\end{array}$ & $\begin{array}{l}\text { CHEMETICS } \\
\text { CHEMETICS } \\
\text { CHEMETICS }\end{array}$ \\
\hline 用 排 水 & $\begin{array}{l}\text { 用水処理 } \\
\text { 排水処理 }\end{array}$ & $\begin{array}{l}\text {; 凝集沈殿槽 } \\
\text { サンドフルー（上水用） } \\
\text {; 中和槽 } \\
\text { クラリファイヤー (50 m } \phi) \\
\text { 天日乾燥床 } \\
\text { 活性污泥処理槽 }\end{array}$ & $\begin{array}{l}4 \text { 式 } \\
1 \text { 式 } \\
1 \text { 槽 } \\
2 \text { 基 }\end{array}$ & $\begin{array}{l}\text { FILSAN } \\
\text { FILSAN } \\
\text { DEGREMONT (B) }\end{array}$ \\
\hline
\end{tabular}




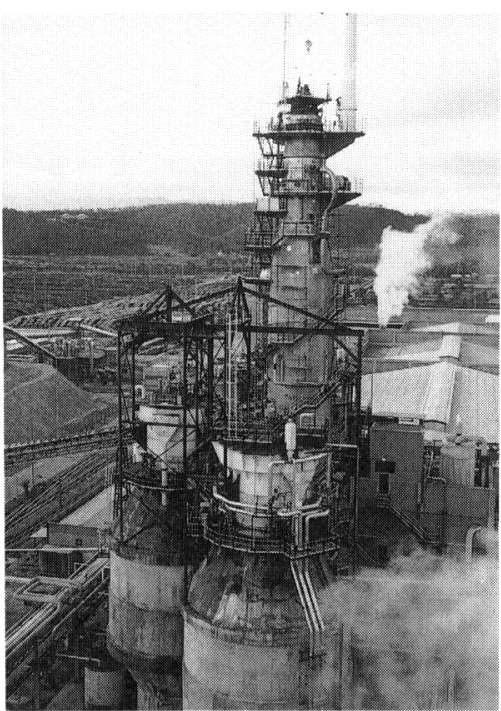

写真 2 新設デフューザー (手前) と木鉒

$\mathrm{O}_{2}$ を吹きこみ, $\mathrm{CE} / \mathrm{OHDED}$ のシーケンスに変更して いる。現在のセニブラ増産の設備的なネックは回収ボ イラーと晒で, 後者はドラムフィルター及び付属機械, スチームミキサー, 高濃度ポンプの各能力がオーバー 気味で設備能力の見直しを行っている。晒の最終 D 段 を通ったパルプは $\mathrm{SO}_{2}$ 水で中和後, 晒高濃度チェスト に貯蔵され，晒スクリン及び Cellecoのクリーナーで 除塵され抄造工程に送られる。

4）抄造・包装・出荷

ブラジルVoithのウェット及びプレスパート並び に Flaktドライヤーで構成されているパルプマシン は，パルプを $12 \%$ 水分まで乾燥し，カッターに送り込 む。 $800 \times 685 \mathrm{~mm}$ にカットされなシートは $250 \mathrm{~kg}$ に 計量, プレス後, 共紙で包装され, 最終的には 8 ベー ルにまとめられ，ワイヤ一掛けして倉庫に格納される。 オーダーに応じ貨車でポートセル港に運ばれ海外向に 船積みされる。ブラジル国内用はトラックで積出され

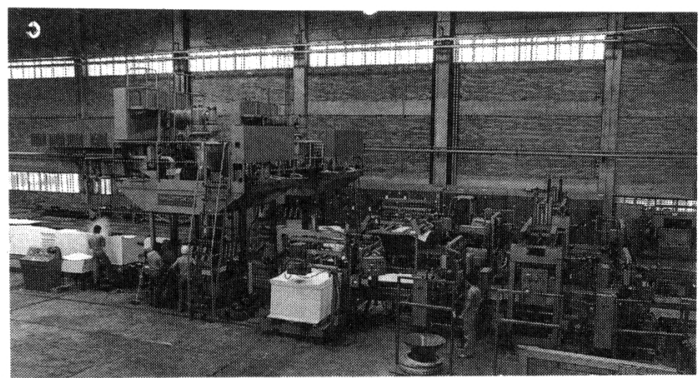

写真 3 パルプの包装ライン

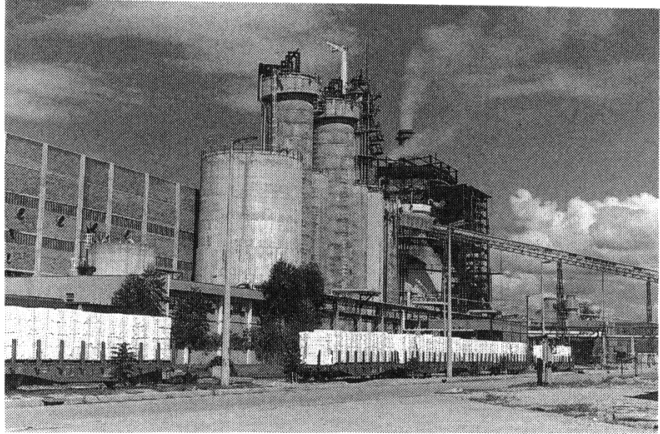

写真 4 ポートセル港向けパルプの積出し 後方は晒塔と回収ボイラー

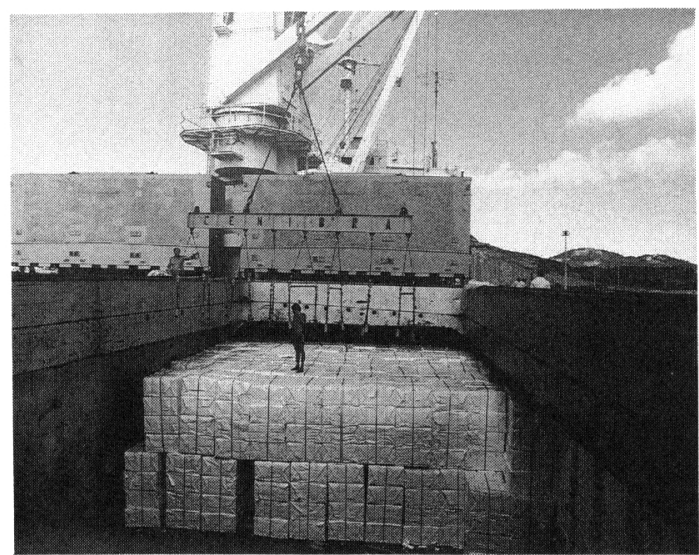

写真 5 ポートセル港で日本向けパルプの船積み

る。

5）品質

パルプ品質は白色度 $91^{\circ} \mathrm{GE}$, 粘度 $10 \mathrm{CP}$ 以上, チリ $0.5 \mathrm{~mm}^{2}$ /パルプ $100 \mathrm{~g}$ 以下が日本向けの輸出適格品 である。このレベルは国際市場で一流品として売買さ れるものである。ユニタイズされ工場倉庫に格納され たパルプは品質管理部の判定が出ないと出荷出来ない 仕組になっている。

6) エバポレーター

洗滌から出た黒液は酸化されて $62 \%$ 迄濃縮される が, 最近の増産で能力不足気味となり，1985 年秋よ り, 2 缶増設, 5 缶 5 重を 6 缶 5 重コンセントレーター 付と能力を増強した。従って濃黒液のより高い且つ安 定した濃度により，負担の大きかった回収ボイラーは やや負荷が軽くなっている。

7）回収ボイラー,バークボイラー

三菱重工製の回収ボイラーは建設時, 日本最大の回 収ボイラーであり，30万tのパルプ生産迄は炉内の ダスト詰りの掃除も2カ月に 1 回位でチューブの噴破 


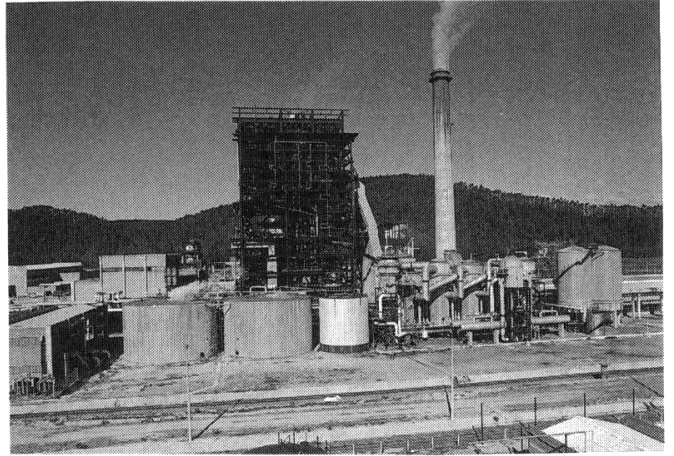

写真 6 回収ボイラー及びエバポレーター

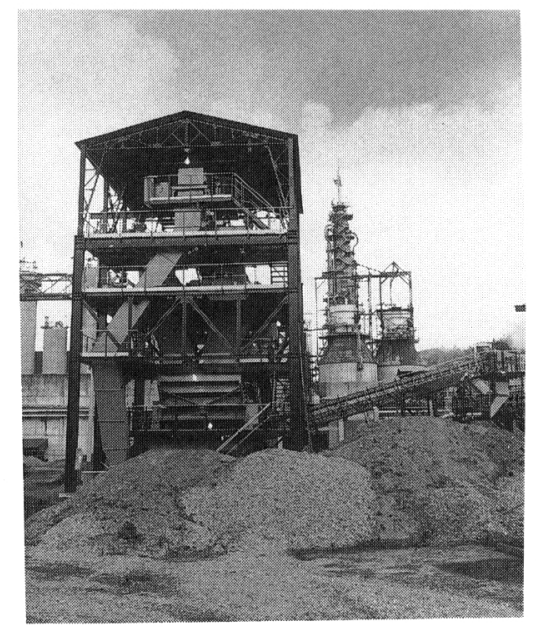

写真 7 燃料用チップ及びバーク 並びにクラッシャー

後方は木金とデフューザー

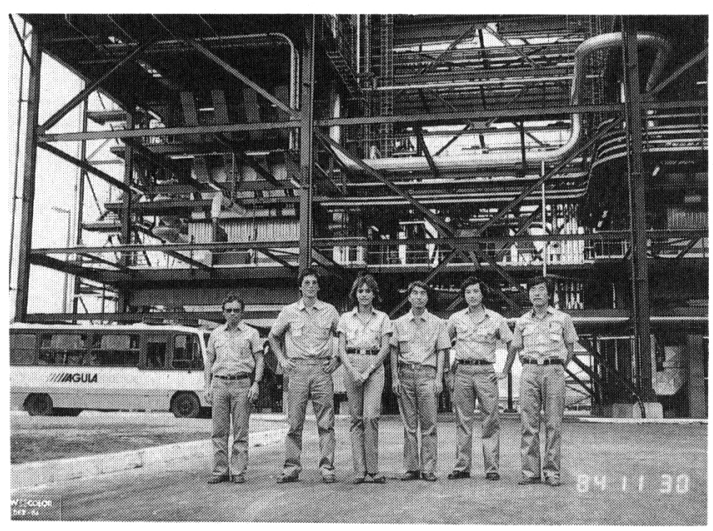

写真 8 バークボイラーの前で

はもちろん無く, 減肉も僅か(計算では 20 年以上使用 可能）であったが，パルプ生産が 30 万tを越えてか ら操業がやや苦しくなっている。オペレーターに対す る安全教育は徹底して行われているが, 回収ボイラー
の爆発は何時, 如何なる時に発生するか予測は出来ず, 安全対策として 1990 年末完成で新回収ボイラーの建 設が始まっている。

パークボイラーはブラジル政府の “原則として重油 使用禁止の政策”により重油ボイラーの償却も未完の まま 1985 年 7 月に完成し, 順調に運転中である。燃料 はチップ及びバークである。

8）苛性化・キルン

苛性化はドル式連続苛性化装置でコンベンショナル 方式の沈降システムを採用している。増産に伴い僅か ながら白液の濁りが上り気味である。

キルンはF．L．スミスのチェン方式を持ったロータ リーロングキルンで石灰当りの重油原単位が極めて良 W。

燃料転換は重油に代るべき代替燃料及び経済性の良 い設備が開発されず凍結中である。

9）タービン・発電機

タービンは東芝製 2 段抽汽復水式, 発電機は BBC 製で容量は 4 万 $\mathrm{kW}$ である。工場の総使用電力量は約 3.5 万 kWであり, ほぼ 90\%を賄っている。残りは M. $\mathrm{G}$ 州中央電力公社から購入している。因みにこの公共 用電力は停電が多くまた電圧変動も大きいので, BO 工場では負荷変動の大きい設備や短時間停電しても影 響のない設備（例 チッパー）にのみ使用している。 微妙な変化を嫌う設備は自家発電を利用している。

回収ボイラー及びパークボイラーからの発生蒸気は それぞれ $200 \mathrm{t} / \mathrm{H}, 90 \mathrm{t} / \mathrm{H}\left(65 \mathrm{~kg} / \mathrm{cm}^{2}, 450^{\circ} \mathrm{C}\right)$ 前後で あり，負荷は回収ボイラー $100 \%$ ，バークボイラー $60 \%$ あ゙あ。

10）晒製薬

晒用薬品は塩素, アルカリ, 次亜塩素酸ソーダ, 二 酸化塩素が使われているが, 何れも原塩の電気分解装 置 $\mathrm{Cl}-\mathrm{Al}$ 電解とクロレート電解を基にしている。日本 の紙パルプ産業では各化学メーカーからこれ等の薬品 を購入しているが, セニブラ・BO 工場の如く僻地に あれば輸送の困難性により購入が難しく, 電解装置を 含め関連設備を設置し自製している。試運転当初, 塩 素液化設備のトラブルにより，半年もの長期にわたつ て停止したが, 改善・修理後はオペレーターの習熟と 共に全設備が安定した生産を続けている。これは日本 からの専門技術者 4 名による設備改善とオペレー夕ー への献身的な技術移転教育によるものである。

最近では晒用薬品原単位の向上により, 設備に余裕 ができ塩素, 苛性ソーダ，塩酸等は一部社外にも販売 している。

11）用水処理 
工場用水は傍のドーセ河から取水している。水は茶 褐色であるが水質は良く短時間の沈降で使用可能とな る。取水能力は 22.5 万 $\mathrm{M}^{3} /$ 日, 常用は 13 万 $\mathrm{M}^{3} /$ 日で ほぼ50\%の負荷である。

12）環境保全

ブラジルの環境保護行政は各州で制定した規準値を もとにして行われ, 監視体制の整備がかなり進んで来 ている。1980 年頃は BO 工場に MG 州の担当官が実 習に来て技術を取得したのどかな時代でもあったが, 附近の住民やドーセ河下流にあるゴベルナドール市 （BO 工場より下流へ $80 \mathrm{~km}$ ) の市民から河の水が黒 くて“臭い, 風向きによっては空から白い粉が降った り, 玉子のくさった臭気が来る”等の苦情が時と共に 次第に出て来たので先ず排水処理, 特に BOD 対策と して活性污泥装置を設置, 既に' 88 年末より調整運転 に入っている。同時に臭気・媒塵対策の設備改善も 行ったので, これ等の設備が完全に働けばドーセ河周 辺からの排水クレームは完全に解消する見込みである。 当初の建設に当って日本側では基本設計の段階より排 水処理, 臭気, 媒塵対策等に就ても或る程度の対策設 備をおり込んで, 運転後も排水路の分離統合による改 善, 石灰による薬注, クラリファイヤーの管理強化と 各所の廃水・排気のデー夕捸取, 更に最終排水口を改 善し暗渠にして発泡を押えること, 媒塵捕集用強力, 電気集塵機の設置, エパポレーター並びに木金の臭気 性ガス燃楛を徹底して行って来たが, 生産の増大によ る排水の悪化に対応できず, 排水処理設備の根本改善 となった。この他, 個々の従業員に環境に対する心構 えを強力に植付ける教育と社内に “環境委員会”を設 置して改善に全力を上げている。因みに M. G 州の公

表 18 ミナス・ジェライス州公害規準値

\begin{tabular}{|c|c|c|}
\hline \multirow[t]{4}{*}{ 水質 } & $\mathrm{pH}$ & $5.0 \sim 9.0$ \\
\hline & 温度 & $40^{\circ} \mathrm{C}$ 以下 \\
\hline & SS & 平均 $60 \mathrm{ppm}$ 以下, 最大 $100 \mathrm{ppm}$ \\
\hline & BOD & $60 \mathrm{ppm}$ 以下 \\
\hline \multirow[t]{7}{*}{ 大気 } & ばいじん & 年間平均 $80 \mu \mathrm{g} / \mathrm{m}^{3}$ 以下 \\
\hline & & 日間最大 $240 \mu \mathrm{g} / \mathrm{m}^{3}$ \\
\hline & $\mathrm{SO}_{2}$ & 年間平均 $80 \mu \mathrm{g} / \mathrm{m}^{3}$ 以下 \\
\hline & & 日間最大 $365 \mu \mathrm{g} / \mathrm{m}^{3}$ \\
\hline & $\mathrm{CO}$ & 最大連続 8 時問 $10,000 \mu \mathrm{g} / \mathrm{m}^{3}$ 以下 \\
\hline & & 1 時間值最大 $\quad 40,000 \mu \mathrm{g} / \mathrm{m}^{3}$ \\
\hline & $\begin{array}{l}\text { 光化学オキ } \\
\text { シダント }\end{array}$ & 1 時間値最大 \\
\hline
\end{tabular}

表 19 燃料転換設 備

\begin{tabular}{lr} 
バークボイラー (バイオマスボイラー) & 2 基 \\
蒸気発生量 $\quad$ 木材のみ燃料 & $75 \mathrm{~T} / \mathrm{H}$ \\
& $100 \mathrm{~T} / \mathrm{H}$ \\
ドラムバーカー 重油混焼 & $5 \mathrm{M} \phi \times 24 \mathrm{~m} l$ \\
原木受入設備（プロセス用及びバーク用） & 2 式 \\
バーククラッシャー & 基 \\
バーク搬送及びチッピング設備(含チッパー) & 2 台 \\
燃料用チップ及びバークヤード \\
既設・新設連絡コンベヤー & 1 式 \\
\hline
\end{tabular}

害規制值は日本以上に厳しい。

\section{4 燃料転換}

多大の外債に苦しんでいるブラジルは 1979 年のオ イルショックを契機に石油の輸入を押える行政指導を 強めて, 紙パルプ産業も 1985 年末までに $87 \%$ の重油 使用量カットの対策を行うことになった。セニブラも 重油に代る燃料として, 長期にわたって経済的かつ安 定して確保できるのは木材と云うことで, バークボイ ラーを発注し 1985 年 7 月より, 重油ボイラーに代って 連続運転中であり既に目標値に到達している。しかし ながら生石灰キルンに就ては技術的・経済的に対応で きる設備の開発が未完成で現状のままとなっている。

なおブラジルでの石油自給率も 1982 年にリオデ ジャネイロ沖の海底油田が発見・採掘され始め，60\% にまで上って来ており,一時の緊迫した気配は薄らい でいる。

今後の問題としては, 重油に代る原木の安定供給を 如何にするか, 土地の購入を含めた植林計画が必要で ある。

\section{5 駐在中の経験に基づく反省と提言}

セニブラの業績を表 20 で見ると生産高は 1980 年以 降順調に伸び（但し 1981 年は発電機の焼損があり除 く）平均日産も $1,030 \mathrm{t}$ で設計スペックを $40 \%$ オー バーする素晴らしい業績をあげている。また収益の方 も市況の影響があってパルプ $\mathrm{t}$ 当りの利益にバラッキ はあるものの徐々に増えており, 特に 1988 年は目覚 しく，セニブラも確固たる基礎ができ上り磐石の体勢 になったと思われる。これは日伯両国関係者のべスト を尽くした努力以外の何ものでもないが，不調が長く 続いた 1977 年のスタートを反省すると,もうすこし両 者が相互の理解をより深く進めていたならばと思い, 私自身の経験から意見を述べ, 今後海外, 特にブラジ ル等へ単独又は合弁企業を作るために進出する際の参 考の一助となれば幸である。

1）進出先は中・後進国である。従ってバックグラ 
表 20 七ニブラ社の業績, パルプ生産と販売高

業 績:

\begin{tabular}{c|c|c|c}
\hline 年 & 生産高 & 売上 高 & 税引後利益 \\
\hline 1978 & 116,122 & 34,079 & $\begin{array}{c}\text { 千ドル } \\
(-) 63,390\end{array}$ \\
\hline 1979 & 214,004 & 80,180 & $(-) 19,201$ \\
\hline 1980 & 279,089 & 116,644 & 8,897 \\
\hline 1981 & 213,110 & 93,606 & 9,886 \\
\hline 1982 & 306,277 & 115,038 & 20,481 \\
\hline 1983 & 298,771 & 99,257 & 28,070 \\
\hline 1984 & 316,558 & 127,558 & 30,197 \\
\hline 1985 & 329,461 & 112,623 & 11,823 \\
\hline 1986 & 344,571 & 123,206 & 17,288 \\
\hline 1987 & 351,056 & 180,868 & 42,554 \\
\hline 1988 & 362,274 & 205,720 & 91,438 \\
\hline
\end{tabular}

パルプ販売 :

(単位: $\mathrm{t}$ )

\begin{tabular}{|c|c|c|c|c|c|c|c|c|}
\hline \multicolumn{2}{|l|}{ 年 } & 1981 & 1982 & 1983 & 1984 & 1985 & 1986 & 1987 \\
\hline 日 & 本 & 112,242 & 159,253 & 152,194 & 154,931 & 143,308 & 147,673 & 168,990 \\
\hline 欧 & 州 & 28,998 & 24,075 & 28,530 & 26,228 & 23,243 & 23,459 & 20,893 \\
\hline × リ & カ & 18,140 & 10,817 & 34,213 & 40,203 & 57,292 & 57,011 & 72,079 \\
\hline アルゼンチ & ン & 15,482 & 35,936 & 13,726 & 9,675 & 8,774 & 4,092 & - \\
\hline コロン ビ & $\boldsymbol{T}$ & 567 & 2,243 & 3,935 & 1,886 & 1,895 & 2,375 & 2,035 \\
\hline ベ ネ ズ エ & ラ & 0 & 0 & 3,999 & 8,042 & 7,994 & 5,495 & - \\
\hline の & 他 & 8,794 & 7,476 & 4,978 & 0 & 2,998 & 1,999 & 999 \\
\hline \multirow[t]{2}{*}{ 輸 } & 出 & 184,223 & 239,800 & 240,758 & 240,965 & 245,504 & 242,104 & 264,996 \\
\hline & $\%$ & 82.7 & 79.8 & 79.8 & 78.7 & 72.2 & 72.0 & 72.0 \\
\hline \multirow[t]{2}{*}{ 国 } & 内 & 38,671 & 60,550 & 61,070 & 65,274 & 94,410 & 94,176 & 103,016 \\
\hline & $\%$ & 17.3 & 20.2 & 20.2 & 21.3 & 27.8 & 28.0 & 28.0 \\
\hline 売 & 計 & 222,894 & 301,350 & 301,645 & 306,239 & 339,914 & 336,280 & 368,012 \\
\hline
\end{tabular}

ンドが劣る。具体的には飲料水，電気，道路等インフ ラが久如している。例えば電気であるが停電, 電圧変 動等はかなり多い。従って水道の断水, 飲料不可も附 随的に発生する。また道路が整備されておらず，交通 の便も悪く日本人の習性として直ぐに汽車を利用しよ うとしても鉄道が少なく便数も無いに等しい。ブラジ ルの場合は鉄道に代りバスが走っており，貨物の移動 はトラックである。国土が広いので航空網は発達して
いるが一般庶民にとっては高嶺の花である。

2）教育水準が低いので，日本人と同じレベルと考 えると大間違いを起す。例えば電気製品, モータ一等 に水をかけてはならないことは日本人には常識でもブ ラジル人の現場作業員は判っていない。従業員の教育 に当ってはそこから出発しなければならない。1981 年 のセニブラ減産の最大理由は発電機の焼損であるが, 掃除を担当するセニブラ従業員が放水して洗浄中，発 
電機とトランスを結ぶブスバーの防水カバーにも熱心 に水をかけて短絡させ，その結果，発電機が焼損した 苦い経験がある。同様にモーターに水をかけて矢張り 焼損させた事故もある。

対策として教育の内容を対象者の職務によって分け たが，その他施設面に“フールプルーフ”で設備を企 業が自ら守る様に実施中である。

3）欧米式に組織は縦のラインがメインであり, 横 のラインは弱い。従って縦のラインの長は部下を即時, 酋或首する程の絶大な権限を持ち, 部下は殆ど意のまま に動く。しかし隣接職場の長の命令には従わなくても 良いことになっている。こうした面では日本と責任権 限の面でやや異っているのでとまどうことがある。要 はラインとスタッフの関係が日本とかなり異ると云う ことである。

4）一方高いサラリー, 良いポストがあれば簡単に 転職する。私の場合, 社宅に居住していて家族どうし の交際の中で妻が “転職・退職”の情報を垷むことが 多かった。これは逆に云うと, ブラジル人の女性は口 が軽いことにもなるが，おかげで早目に対処できた。 速かな情報の収集が重要である。

5）ブラジル人の国民性は一般に楽天的で新しがり 屋で且つ飽きやすい。このため新しい装置, 機材の紹 介, 売り込みがあると直ぐに飛び付く。慎重な検討が されない訳である。これはむしろインテリの方に多い かも知れない。国家的に考えても, 建設中途で中止し た原子力発電, ブラジル中部の “鉄鋼鉄道” 等数之上 げればキリがない。所謂無計画な“メガトロマニア” “巨大主義”がまかり通っている。その他イタイブーの 水力発電能力は世界一であるが, 未だ発電量は $30 \%$, 送電線も能力不足, 更にはこの電力を活用する産業が 近くにない。遠い将来には活用されるが，それ迄の金 利を含む㕃大な償却を如何にすれば良いか他人事なが ら気になるところである。

6）上記の様なことに対する責任は刑事事件や破廉 恥罪でもなければあまり追求されない。一般職を首或首 することは容易だが, かかるプロジェクトの場合は対 象が幹部クラスでありあまり明確でなく企業でも同様 である。なおブラジル人の場合は余程明白な証拠や事 実がないと謝ることは少ない。謝ることは罪を認める ことになり，罰を受けざるを得ない。ただ日本人に仕 えた彼等も日本人の場合は滅多に藏首しないことが判 ると割に正直に謝る様になった。

7）誇り高きブラジル人が多いためか, 判らないこ と, 知らないことも“判った” “知っている”等, 嘘を 云うことが多い。これは計画立案, 操業等害務面で重
大支障をきたすことになり，引いては設備を破損して しまうことになる。こうした意味では日本人が部下に 任せる方式は仲々やり難い。慎重な対応が必要である。

8）土建関係の技術力はサンパウロ，リオデジャネ イロの林立する高層建築物を見て非常に勝れていると 思ったが, セニブラでは操業スタート時に構造物や設 備の基礎等に大きなトラブルが下記の如く次々と発生 した。複雑な設計に対する技術力はあまり高くない様 である。

第一番目は回収ボイラー附属の電気集塵器の構造物 であるコンクリートの強度が無く建て直した。二番目 は晒タワーで, 漏水試験で水を張ったところ， 6 本の タワー全部に縦状の亀裂が入り, 対策として外周は上 下全部にバンド掛け補強とタイルの張り替え及び二重 張りを行った。原因は鉄筋の配列をミスして建設した ことである。三番目は同じ晒 $\mathrm{D}_{1}$ タワーの底が抜けた ことで, タワー設計時の強度計算の間違いと施工時の 施工者のミス工事である。四番目は回収ボイラーの誘 引ファンの振動が直ぐに発生したことで, 当初のプレ ンメタル不良かランナーの芯狂い等機械的事故と判断 していたが解消されず, ファンの基礎強度計算の地耐 力計算ミスと判り, ベースの補強を行い以後は安定し ている。五番目は 4 基ある液体塩素タンクの基礎が弱 く片側に傾き始めたのでベースの補強を行い事なきを 得た。

9） 日本のモーターではあまり経験していないが, ブラジル製の $\mathrm{A}$ 社のモーターは再三にわたって定格電 流の 70 ８0\%でサーマルが働いたり焼損するので修 理をさせたが改善されず1ランク上のモーターに凡て 切替えた。他のユーザーの情報でも慎重なユーザーは ブラジル国産のモーターを使用する時は 1 ランク上の ものを購入すると云うことである。なお，このモー ターメーカーはアメリカの有名なメーカーの子会社で あり，名前だけでは信用出来ないことも判った。また $\mathrm{B}$ 社製の高圧モーターは能力には問題はなかったが, ローターサイドの押え銅製リングが切れステーターを 傷付け焼損する事故が続いた。問題は焼損の影響で高 電圧により各所のトランスが働き, 或る時はローカル 停止, 或る時は工場全停止等のトラブル, 更に連続的 に弱い他の電気設備に波及し焼損して長時間の停止を 起こしたことであり，モーターの補充がつかず，やり くりは8)の晒タワー故障で晒のシーケンス変更が長 期にわたったことで間に合い, 表面的には大トラブル として浮かび上らなかったものである。

原因はメーカーが購入していたモーター用材料の銅 板の品質不良であった。 
全般に国産の電気製品は素材である原材料の品質が 劣る様である。

10）工場には各エリア或はローカルに電気ボック スを収容している電気室が配置され, 各シーケンス設 備も並居しているが，この中にはトランスジスター, ダイオードや半導体等が格納されている。これ等が正 常操業中にしばしばパンクするのでよく調べた所, 室 内温度が異常に上昇していることが判りクーラーを追 加購入した。原因は内蔵されているスイッチ等から発 生する熱量計算が間違っていたもので，大多数の電気 室が同じ状態であった。こう云ったくだらない理由に よるトラブルが試運転当初はしばしば発生したが，セ ニブラでも熟練した技術者が不足していて解決を長引 かせた。

11）色々報告も出ているが, 水源地の揚水ポンプ のランナー材質が不良で数力月で駄目になってしまっ た。これに就てはポンプメーカーの言うことをそのま ま信用したためであり, 当初の指摘事項即ち自分で確 認することを意った為である。

12）塩素製造設備の塩素コンプレッサーの修理は 1978 年 1 月より 8 月まで丁度 7 カを要した。原因は 下記の通りであった。

(1)電気分解設備により発生した塩素ガスの脱湿能力 が小さく限度ギリギリであった。

(2)メンテナンス後のスタート時の系統内乾燥が不完 全のまま運転したので，コンプレッサー内部及び 関連設備に損傷（腐蝕）を与えてしまったこと。

(3)輸入部品（アメリカ及びスイス）の申請手続きの 遅延及び担当官庁の不慣れ。

従って内部損傷のダメージが大きい上に取替えるべ き部品の入荷に時間がかかったことである。この期間 は必要薬品 “塩素, 苛性ソーダ”は凡て購入したがブ ラジル国内の塩素運搬車の不足, 輸送距離が 400 $\sim 1,200 \mathrm{~km}$ と非常に離れていることで必要量を十分 入手出来なかった。塩素乾燥塔增設と若干の設備改善 並びに塩素ガス中の水分チェックの強化後はトラブル は殆ど解消した。基本的には塩素製造設備に対する知 識不足が原因であったと反省している。

13）最近までトラブルと云うか, 工場全停止を起 しているのがタービンのトリップである。高圧モー タ一焼損によるものも含め年に数回発生し未だに完全 解決に至っていない。原因としては夕ービン本体, 関 連設備, 操業未熟等が考えられる。

(1)夕ービン内オイルの循環不足 (M. O. P 焼損他)

(2)夕ービン内循環オイルの污れ（"）

(3)或るエリアでの高圧モータ一焼損等による電圧降
下等のショック

(4)エリアのメーントランスのケーブルを鼠が嚙って 短絡したことによるショック

(5)操業面での負荷の急激な変化（蒸気の過不足）と タービンオペレーターの運転技術の未熟（オー バーアクション)

(6) 原因不明

等があり，少なく共(1)，(2)は改善されているが(3)，(5)， (6)は完全解決に至っていない。

基本的に電気の設計に問題があるのか, 総合的な電 気のシーケンスに問題があるのか, 或いはブラジル製 の電気材料器具が不良（作動に対する信頼性）なのか 判らないのが実体と思う。

14）デフュージョンウォッシャーのトラブルは生 産品への影響はあまり無かったが, 排水不良及び回収 芒硝の不足を来した（約 $3 \%$ 低下）。この事故は昇降 装置の故障時にもパルプ洗滌と云う機能を働かせよう とした為，ストレーナーを変形・破損させてしまった もので操業技術の勉強不足につきる。

15). エバポレーターの 1 号缶の蒸気ドレンに黒液 が逆流, この発見がおくれ（電導度計が狂っていた） メーンのドレンタンクより各ボイラーにまで黒いドレ ンが流れた事故が発生した。工場を全停止，ボイラー 全チューブを 36 時間連続で水洗した。原因は上記 1 号 缶の蒸気弁の切替間違いによる操業ミスである。なお, 1978 年のボイラー定期点検で各スーパーヒーターの チューブを切り取り, 内部のスケールを点検したが, タービンのローターを含め全く異常は認められなかっ た。

16）12）で述べた塩素がスの水分除去用濃硫酸タン クの側板及び天井が硫酸ミストで腐蝕する為, 保全担 当者がゴムライニングを計画したが，ライニング用の ゴムが耐濃硫酸用であると云う某社の説明を信じて確 認テストを行わず，工事を行っていたのでテストした ところゴムが溶出することが判った。元来, この濃硫 酸はR-3の二酸化塩素発生装置に使用されるもので, 微量の有機物が混入するのみでもパフを起す危険性を 自ら作り出す様なものであった。11) と同様に自分自 身で確認しないことが問題であると共に危険性をよく 知らなかった面もある。

17）晒 $\mathrm{D}_{1}, \mathrm{D}_{2}, \mathrm{C}$ 各ドラムフィルターは $317 \mathrm{~L}$ の材 質であったが，クローズドシステムの為か，ピッチン グの腐蝕が始まり 1981，'82，'83 年にかけてチタン製 に全部取替えた。この原因は $\mathrm{D}_{1}, \mathrm{D}_{2}$ ドラムフィルター は残留二酸化塩素に対する亜硫曹の添加不足であった。 Cドラムフィルターは腐蝕の報告が世界的に少なく安 
心していたが，公害对策によるクローズドシステムの 影響か，最近は腐蝕の実例が各地で報告されている同 じ現象と思われる。

18） Digesterの溶接線にクラック発生, 2)項の 1981 年の発電機焼損事故で 3 力月間工場全停止時に 全設備のチェックを行い, Digester の溶接部にへヤー クラックが発生しているのを発見，全溶接線に亘って 調査したところ一番深いものは金の底部で，肉厚 35 $\mathrm{mm} に 17 \mathrm{~mm}$ あり，全溶接線の開先取り及び再溶接 を実施した。原因はアルカリ脆化によるものと，最初 の木鉒製溶接時の不良による複合クラックの発生と 思われる（建設時の溶接不良は溶接検査表の再チェッ クで発見されたものであり，工事業者及び監督業務の ミスである)。溶接の修理方法はスウェーデン方式 (焼鈍なし)ではなく，日本で行う通常方式(焼鈍温度 $180 \sim 200^{\circ} \mathrm{C}$ ，約 8 時間）で行った。

この修理はブラジル人技師をチーフとして，ボイ ラーメーカーである $\mathrm{C}$ 社の優秀な現地人の溶接工，七 ニブラ社の溶接及び補助員並びにスタッフとしての日 本人技師でチームを組む文字通り日伯一体となって行 われた。特に限られた期間内にかつ鉒内の高温, 換気 不良, 高所作業等の悪条件下での突貫工事であったが 見事に予定通り完了した。

この時にはブラジル人技師にも日本人と同じ考え， 同じ努力をする者も居ることが判り，あらためてブラ ジル塊を認識させられた。

以上の様な各種のトラブルが当初は発生して生産が 順調に進展しなかった。特にブラジル側管理職クラス のマネージメント不足, 保全部門（機械, 電気, 計装, 土建，予防保全）動力部門の実務的及び技術レベルの 能力不足が甚だしく，連続的なトラブルによるモラー 儿低下対策を含め, 1978 年 10 月より従来ブラジル側 が持っていた工場の運営を一時的に日本主導型で行う ことになり下記の形となった。

(1)日本人の技術担当取締役が工場長を兼務し工場運 営に当る(本来はスタッフ業務である)。

(2) メンテナンス部門の技能アップのため日本より 専門の技術者を派遣する。特に実務面での能力 アップと予防保全の技術移転。

これが技術移転の内容で 1978 年 10 月より延 40 名 の日本人技術者が保全, 動力, 唒製薬部門のラインに 入り, ラインの長としてブラジル人管理・監督者（ポ スト就任予定者）にはマネージメント，それ以下の者 には実務を OJT 方式で教育した。期間は受講者の技 能が，充分安定操業を続けられる様になるまで最小 2 年, 最大 3.5 年 (1978 年 9 月より 1982 年 3 月迄)にわ
たって行われた。マネージメントとしては

(1)生産・品質に対する強い責任感の醸成

(2)職場間の緊密な連繫・援助

(3)部下への教育と指導

技能工に対しては

(1)技術の向上

(2)仕事に対する責任感の育成

業務としては特に予防保全の整備・強化を狙うこと として

(1)予備品の管理

(2)設備の履歴調査, 短・中期の修理計画立案

(3)設備の診断, 日々のデー夕採取

等を主として指導し技術移転を行った。

動力及び晒製薬部門は操業技術レベルの向上に主眼 をおき安全運転第一に徽する様につとめた。

製造部門は管理職対象にマネージメントに関して教 育を行ったが，所属長には自己の職場の生産・品質に 全責任があることと，隣接職場との密接な連繫プレー を取ることを強調して教育した。

特に派遣日本人技術者は，常にブラジル人より勤勉 であり，自ら実行し範を垂れ，自分の身体で教え，ブ ラジル人が理解・納得し尊敬する様な教育をすること でこの技術移転計画は成功したと思っている。そして 現在も人去り人移ってもセニブラの B. O 工場には日 本の紙パルプ業界の持っている技術が，精神が受け継 がれて拡がって行くことを願っている。

特に私個人としては，パルプ品質については世界に 通用する最高水準を維持することと, 設備面と安全面 から回収ボイラーの運転・保守には定められた基準を 厳守することをモットーにして厳しく指導して来た。

折しも JARI では回収ボイラーのトラブルが一昨年 発生し, 約 8 力月間停止したとのことであるがセニブ ラではこの点だけは起らないと信じている。

\section{あとがき}

既にセニブラの第二期 35 万 $\mathrm{t}$ 計画が始まったと聞 いているが，今回は過去の経験を活かし，前者の轍を 踏まぬ様に速やかに成功することを期待している。

私にとってもブラジルは早や遥かに遠くなったが, ブラジルで培ったブラジル人との友情は今も綿々と続 いている。人と人との出合い，そして生れた友情は国 籍, 人種を問わず素晴らしいものであり, 今後共セニ ブラの発展が日伯友好のかけはしとして益々盛んにな ることを祈って擱筆する。

筆者は王子製紙(侏)より日伯紙パルプ資源開発(侏)に出 向し, 七ニブラ社の技術担当取締役として 1976 年より 1985 年まで 9 年間現地に駐在した。 